4

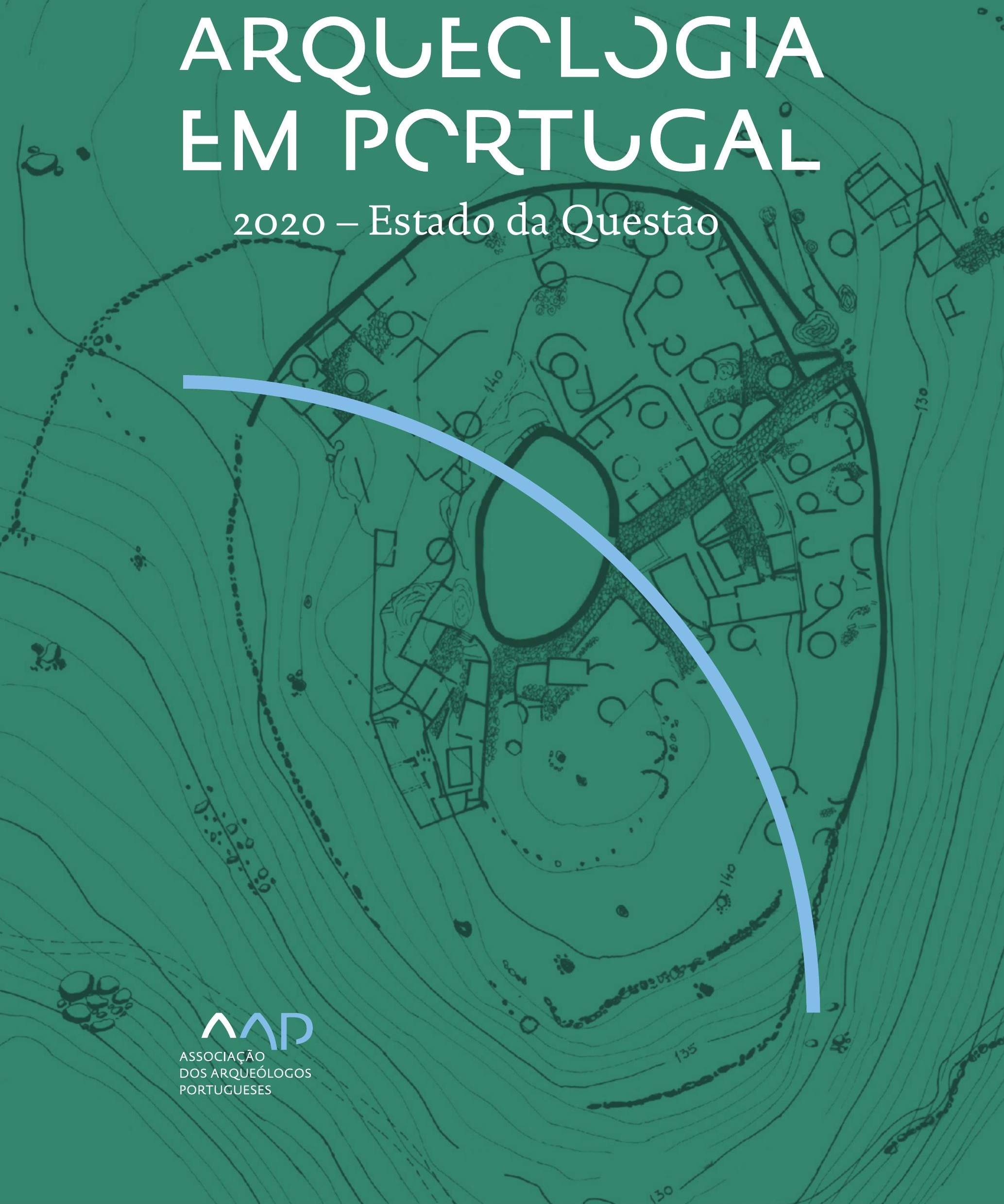


Coordenação editorial: José Morais Arnaud, César Neves e Andrea Martins Design gráfico: Flatland Design

AAP - ISBN: 978-972-9451-89-8

CITCEM - ISBN: 978-989-8970-25-1

Associação dos Arqueólogos Portugueses e CITCEM

Lisboa, 2020

O conteúdo dos artigos é da inteira responsabilidade dos autores. Sendo assim a Associação dos Arqueólogos Portugueses declina qualquer responsabilidade por eventuais equívocos ou questões de ordem ética e legal.

Desenho de capa:

Planta do castro de Monte Mozinho (Museu Municipal de Penafiel).

\section{$\hat{\wedge} \mathrm{P}$}

DOS ARQUEÓLOGOS PORTUGUESES

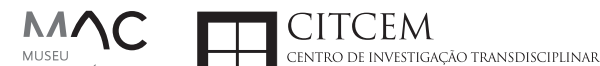
MUSEU
ARQUELLÓGICO
DO CARMO
U.PORTO

FLUP FACULDADE DE LETRAS
UNIVERSIDADE DO PORTO

Apoio

EC para a Ciência 


\section{Índice}

15 Prefácio

José Morais Arnaud

\section{Historiografia e Teoria}

17 Território, comunidade, memória e emoção: a contribuição da história da arqueologia (algumas primeiras e breves reflexões)

Ana Cristina Martins

25 Como descolonizar a arqueologia portuguesa?

Rui Gomes Coelho

41 Arqueologia e Modernidade: uma revisitação pessoal e breve de alguns aspetos da obra homónima de Julian Thomas de 2004

Vítor Oliveira Jorge

57 Dados para a História das Mulheres na Arqueologia portuguesa, dos finais do século XIX aos inícios do século XX: números, nomes e tabelas

Filipa Dimas / Mariana Diniz

73 Retractos da arqueologia portuguesa na imprensa: (in)visibilidades no feminino

Catarina Costeira / Elsa Luís

85 Arqueologia e Arqueólogos no Norte de Portugal Jacinta Bugalhão

101 Vieira Guimarães (1864-1939) e a arqueologia em Tomar: uma abordagem sobre o território e as gentes

João Amendoeira Peixoto / Ana Cristina Martins

115 Os memoráveis? A arqueologia algarvia na imprensa nacional e regional na presente centúria (2001-2019): características, visões do(s) passado(s) e a arqueologia

enquanto marca

Frederico Agosto / João Silva

129 A Evolução da Arqueologia Urbana e a Valorização Patrimonial no Barlavento Algarvio: Os casos de Portimão e Silves

Artur Mateus / Diogo Varandas / Rafael Boavida

\section{Gestão, Valorização e Salvaguarda do Património}

145 O Caderno Reivindicativo e as condições de trabalho em Arqueologia Miguel Rocha / Liliana Matias Carvalho / Regis Barbosa / Mauro Correia / Sara Simões / Jacinta Bugalhão / Sara Brito / Liliana Veríssimo Carvalho / Richard Peace / Pedro Peça / Cézer Santos

155 Os Estudos de Impacte Patrimonial como elemento para uma estratégia sustentável de minimização de impactes no âmbito de reconversões agrícolas Tiago do Pereiro

165 Salvaguarda de Património arqueológico em operações florestais: gestão e sensibilização Filipa Bragança / Gertrudes Zambujo / Sandra Lourenço / Belém Paiva / Carlos Banha / Frederico Tatá Regala / Helena Moura / Jacinta Bugalhão / João Marques / José Correia / Pedro Faria / Samuel Melro

179 Os valores do Património: uma investigação sobre os Sítios Pré-históricos de Arte Rupestre do Vale do Rio Côa e de Siega Verde José Paulo Francisco 
189 Conjugando recursos arqueológicos e naturais para potenciar as visitas ao Geoparque Litoral de Viana do Castelo (Noroeste de Portugal)

Hugo A. Sampaio / Ana M.S. Bettencourt / Susana Marinho / Ricardo Carvalhido

203 Áreas de Potencial Arqueológico na Região do Médio Tejo: Modelo Espacial Preditivo Rita Ferreira Anastácio / Ana Filipa Martins / Luiz Oosterbeek

223 Património Arqueológico e Gestão Territorial: O contributo da Arqueologia para a revisão do PDM de Avis

Ana Cristina Ribeiro

237 A coleção arqueológica do extinto Museu Municipal do Porto - Origens, Percursos e Estudos

Sónia Couto

251 Valpaços - uma nova carta arqueológica

Pedro Pereira / Maria de Fátima Casares Machado

263 Arqueologia na Cidade de Peniche

Adriano Constantino / Luís Rendeiro

273 Arqueologia Urbana: a cidade de Lagos como caso de Estudo Cátia Neto

285 Estratégias de promoção do património cultural subaquático nos Açores. O caso da ilha do Faial

José Luís Neto / José Bettencourt / Luís Borges / Pedro Parreira

297 Carta Arqueológica da Cidade Velha: Uma primeira abordagem

Jaylson Monteiro / Nireide Tavares / Sara da Veiga / Claudino Ramos / Edson Brito /

Carlos Carvalho / Francisco Moreira / Adalberto Tavares

311 Antropologia Virtual: novas metodologias para a análise morfológica e funcional Ricardo Miguel Godinho / Célia Gonçalves

\section{Didáctica da Arqueologia}

327 Como os projetos de Arqueologia podem contribuir para uma comunidade culturalmente mais consciente Alexandra Figueiredo / Claúdio Monteiro / Adolfo Silveira / Ricardo Lopes

337 Educação Patrimonial - Um cidadão esclarecido é um cidadão ativo! Ana Paula Almeida

351 A aproximação da Arqueologia à sala de aula: um caso de estudo no $3^{\circ}$ ciclo do Ensino Básico Luís Serrão Gil

363 Arqueologia 3.o - Pensar e comunicar a Arqueologia para um futuro sustentável Mónica Rolo

377 “Conversa de Arqueólogos" - Divulgar a Arqueologia em tempos de Pandemia Diogo Teixeira Dias

389 Escola Profissional de Arqueologia: desafios e oportunidades Susana Nunes / Dulcineia Pinto / Júlia Silva / Ana Mascarenhas

399 Os Museus de Arqueologia e os Jovens: a oferta educativa para o público adolescente Beatriz Correia Barata / Leonor Medeiros

411 O museu universitário como mediador entre a ciência e a sociedade: o exemplo da secção de arqueologia no Museu de História Natural e da Ciência da Universidade do Porto (MHNC-UP)

Rita Gaspar 
421 Museu de Lanifícios: Real Fábrica de Panos. Atividades no âmbito da Arqueologia Beatriz Correia Barata / Rita Salvado

427 Arqueologia Pública e o caso da localidade da Mata (Torres Novas) Cláudia Manso / Ana Rita Ferreira / Cristiana Ferreira / Vanessa Cardoso Antunes

431 Do sítio arqueológico ao museu: um percurso (também) didático Lídia Fernandes

447 Estão todos convidados para a Festa! E para dançar também... O projecto do Serviço Educativo do Museu Arqueológico do Carmo na $5^{\underline{a}}$ Edição da Festa da Arqueologia Rita Pires dos Santos

459 O “Clã de Carenque”, um projeto didático de arqueologia Eduardo Gonzalez Rocha

469 Mediação cultural: peixe que puxa carroça nas Ruínas Romanas de Troia Inês Vaz Pinto / Ana Patrícia Magalhães / Patrícia Brum / Filipa Santos

481 Didática Arqueológica, experiências do Projeto Mértola Vila Museu Maria de Fátima Palma / Clara Rodrigues / Susana Gómez / Lígia Rafael

\section{Arte Rupestre}

497 Os inventários de arte rupestre em Portugal Mila Simões de Abreu

513 O projeto FIRST-ART - conservação, documentação e gestão das primeiras manifestações de arte rupestre no Sudoeste da Península Ibérica: as grutas do Escoural e Maltravieso Sara Garcês / Hipólito Collado / José Julio García Arranz / Luiz Oosterbeek / António Carlos Silva / Pierluigi Rosina / Hugo Gomes / Anabela Borralheiro Pereira / George Nash / Esmeralda Gomes / Nelson Almeida / Carlos Carpetudo

523 Trabalhos de documentação de arte paleolítica realizados no âmbito do projeto PalæoCôa André Tomás Santos / António Fernando Barbosa / Luís Luís / Marcelo Silvestre / Thierry Aubry

537 Imagens fantasmagóricas, silhuetas elusivas: as figuras humanas na arte do Paleolítico Superior da região do Côa Mário Reis

$55^{1}$ Os motivos zoomórficos representados nas placas de tear de Vila Nova de São Pedro (Azambuja, Portugal) Andrea Martins / César Neves / José M. Arnaud / Mariana Diniz

571 Arte Rupestre do Monte de Góios (Lanhelas, Caminha). Síntese dos resultados dos trabalhos efectuados em 2007-2009 Mário Varela Gomes

599 Gravuras rupestres de barquiformes no Monte de S. Romão, Guimarães, Noroeste de Portugal Daniela Cardoso

613 Círculos segmentados gravados na Bacia do Rio Lima (Noroeste de Portugal): contributos para o seu estudo Diogo Marinho / Ana M.S. Bettencourt / Hugo Aluai Sampaio

631 Equídeos gravados no curso inferior do Rio Mouro, Monção (NW Portugal). Análise preliminar Coutinho, L.M. / Bettencourt, A.M.S / Sampaio, Hugo A.S

645 Paletas na Arte Rupestre do Noroeste de Portugal. Inventário preliminar Bruna Sousa Afonso / Ana M. S. Bettencourt / Hugo A. Sampaio 


\section{Pré-História}

661 O projeto Miño/Minho: balanço de quatro anos de trabalhos arqueológicos Sérgio Monteiro-Rodrigues / João Pedro Cunha-Ribeiro / Eduardo Méndez-Quintas / Carlos Ferreira / Pedro Xavier / José Meireles / Alberto Gomes / Manuel Santonja / Alfredo Pérez-González

677 A ocupação paleolítica da margem esquerda do Baixo Minho: a indústria lítica do sítio de Pedreiras 2 (Monção, Portugal) e a sua integração no contexto regional Carlos Ferreira / João Pedro Cunha-Ribeiro / Sérgio Monteiro-Rodrigues / Eduardo Méndez-Quintas / Pedro Xavier / José Meireles / Alberto Gomes / Manuel Santonja / Alfredo Pérez-González

693 O sítio acheulense do Plistocénico médio da Gruta da Aroeira Joan Daura / Montserrat Sanz / Filipa Rodrigues / Pedro Souto / João Zilhão

703 As sociedades neandertais no Barlavento algarvio: modelos preditivos com recurso aos SIG

Daniela Maio

715 A utilização de quartzo durante o Paleolítico Superior no território dos vales dos rios Vouga e Côa

Cristina Gameiro / Thierry Aubry / Bárbara Costa / Sérgio Gomes / Luís Luís / Carmen Manzano / André Tomás Santos

733 Uma perspetiva diacrónica da ocupação do concheiro do Cabeço da Amoreira (Muge, Portugal) a partir da tecnologia lítica Joana Belmiro / João Cascalheira / Célia Gonçalves

745 Novos dados sobre a Pré-história Antiga no concelho de Palmela. A intervenção arqueológica no sítio do Poceirão I

Michelle Teixeira Santos

757 Problemas em torno de Datas Absolutas Pré-Históricas no Norte do Alentejo Jorge de Oliveira

771 Povoamento pré-histórico nas áreas montanhosas do NO de Portugal: o Abrigo 1 de Vale de Cerdeira Pedro Xavier / José Meireles / Carlos Alves

783 Apreciação do povoamento do Neolítico Inicial na Baixa Bacia do Douro. A Lavra I (Serra da Aboboreira) como caso de estudo Maria de Jesus Sanches

797 O Processo de Neolitização na Plataforma do Mondego: os dados do Sector C do Outeiro dos Castelos de Beijós (Carregal do Sal)

João Carlos de Senna-Martinez / José Manuel Quintã Ventura / Andreia Carvalho / Cíntia Maurício

823 Novos trabalhos na Lapa da Bugalheira (Almonda, Torres Novas) Filipa Rodrigues / Pedro Souto / Artur Ferreira / Alexandre Varanda / Luís Gomes / Helena Gomes / João Zilhão

837 A pedra polida e afeiçoada do sítio do Neolítico médio da Moita do Ourives (Benavente, Portugal)

César Neves

857 Casal do Outeiro (Encarnação, Mafra): novos contributos para o conhecimento do povoamento do Neolítico final na Península de Lisboa.

Cátia Delicado / Carlos Maneira e Costa / Marta Miranda / Ana Catarina Sousa

873 Stresse infantil, morbilidade e mortalidade no sítio arqueológico do Neolítico Final/ Calcolítico ( $4^{\circ}$ e $3^{\circ}$ milénio a.C.) do Monte do Carrascal 2 (Ferreira do Alentejo, Beja) Liliana Matias de Carvalho / Sofia N. Wasterlain 
885 Come together: O Conjunto Megalítico das Motas (Monção, Viana do Castelo) e as expressões Campaniformes do Alto Minho Ana Catarina Basílio / Rui Ramos

899 Trabalhos arqueológicos no sítio Calcolítico da Pedreira do Poio Carla Magalhães / João Muralha / Mário Reis / António Batarda Fernandes

913 O sítio arqueológico de Castanheiro do Vento. Da arquitectura do sítio à arquitectura de um território João Muralha Cardoso

925 Estudo zooarqueológico das faunas do Calcolítico final de Vila Nova de São Pedro (Azambuja, Portugal): Campanhas de 2017 e 2018 Cleia Detry / Ana Catarina Francisco / Mariana Diniz / Andrea Martins / César Neves / José Morais Arnaud

943 As faunas depositadas no Museu Arqueológico do Carmo provenientes de Vila Nova de São Pedro (Azambuja): as campanhas de 1937 a 1967 Ana Catarina Francisco / Cleia Detry / César Neves / Andrea Martins / Mariana Diniz / José Morais Arnaud

959 Análise funcional de material lítico em sílex do castro de Vila Nova de S. Pedro (Azambuja, Portugal): uma primeira abordagem Rafael Lima

971 O recinto da Folha do Ouro 1 (Serpa) no contexto dos recintos de fossos calcolíticos alentejanos

António Carlos Valera / Tiago do Pereiro / Pedro Valério / António M. Monge Soares

\section{Proto-História}

987 Produção de sal marinho na Idade do Bronze do noroeste Português. Alguns dados para uma reflexão

Ana M. S. Bettencourt / Sara Luz / Nuno Oliveira / Pedro P. Simões / Maria Isabel C. Alves / Emílio Abad-Vidal

1001 A estátua-menir do Pedrão ou de São Bartolomeu do Mar (Esposende, noroeste de Portugal) no contexto arqueológico da fachada costeira de entre os rios Neiva e Cávado Ana M. S. Bettencourt / Manuel Santos-Estévez / Pedro Pimenta Simões / Luís Gonçalves

1015 O Castro do Muro (Vandoma/Baltar, Paredes) - notas para uma biografia de ocupação da Idade do Bronze à Idade Média

Maria Antónia D. Silva / Ana M. S. Bettencourt / António Manuel S. P. Silva / Natália Félix

1031 Do Bronze Final à Idade Média - continuidades e hiatos na ocupação de Povoados em Oliveira de Azeméis João Tiago Tavares / Adriaan de Man

1041 As faunas do final da Idade do Bronze no Sul de Portugal: leituras desde o Outeiro do Circo (Beja)

Nelson J. Almeida / Íris Dias / Cleia Detry / Eduardo Porfírio / Miguel Serra

1055 A Espada do Monte das Oliveiras (Serpa) - uma arma do Bronze Pleno do Sudoeste Rui M. G. Monge Soares / Pedro Valério / Mariana Nabais / António M. Monge Soares

1065 São Julião da Branca (Albergaria-a-Velha) - Investigação e valorização de um povoado do Bronze Final

António Manuel S. P. Silva / Paulo A. P. Lemos / Sara Almeida e Silva / Edite Martins de Sá

1083 Do castro de S. João ao Mosteiro de Santa Clara: notícia de uma intervenção arqueológica, em Vila do Conde Rui Pinheiro 
1095 O castro de Ovil (Espinho), um quarto de século de investigação - resultados e questões em aberto

Jorge Fernando Salvador / António Manuel S. P. Silva

1111 O Castro de Salreu (Estarreja), um povoado proto-histórico no litoral do Entre Douro e Vouga

Sara Almeida e Silva / António Manuel S. P. Silva / Paulo A. P. Lemos / Edite Martins de Sá

1127 Castro de Nossa Senhora das Necessidades (Sernancelhe): uma primeira análise artefactual Telma Susana O. Ribeiro

${ }_{1141}$ A cividade de Bagunte. O estado atual da investigação Pedro Brochado de Almeida

1153 Zoomorfos na cerâmica da Idade do Ferro no NW Peninsular: inventário, cronologias e significado Nuno Oliveira / Cristina Seoane

1163 Vasos gregos em Portugal: diferentes maneiras de contar a história do intercâmbio cultural na Idade do Ferro

Daniela Ferreira

1175 Os exotica da necrópole da Idade do Ferro do Olival do Senhor dos Mártires (Alcácer do Sal) no seu contexto regional

Francisco B. Gomes

\section{Antiguidade Clássica e Tardia}

1191 O uso de madeira como combustível no sítio da Quinta de Crestelos (Baixo Sabor): da Idade do Ferro à Romanização Filipe Vaz / João Tereso / Sérgio Simões Pereira / José Sastre / Javier Larrazabal Galarza / Susana Cosme / José António Pereira / Israel Espi

1207 Cultivos de Época Romana no Baixo Sabor: continuidade em tempos de mudança? João Pedro Tereso / Sérgio Simões Pereira / Filipe Santos / Luís Seabra / Filipe Vaz

1221 A casa romana na Hispânia: aplicação dos modelos itálicos nas províncias ibéricas Fernanda Magalhães / Diego Machado / Manuela Martins

1235 As pinturas murais romanas da Rua General Sousa Machado, n. ${ }^{5}$ 1, Chaves José Carvalho

1243 Trás do Castelo (Vale de Mir, Pegarinhos, Alijó) - Uma exploração agrícola romana do Douro

Tony Silvino / Pedro Pereira

1255 A sequência de ocupação no quadrante sudeste de Bracara Augusta: as transformações de uma unidade doméstica Lara Fernandes / Manuela Martins

1263 Os Mosaicos com decoração geométrica e geométrico-vegetalista dos sítios arqueológicos da área do Conuentus Bracaraugustanus. Novas abordagens quanto à conservação, restauro, decoração e datação Maria de Fátima Abraços / Licínia Wrench

1277 “Casa Romana” do Castro de São Domingos (Cristelos, Lousada): Escavação, Estudo e Musealização Paulo André de P. Lemos

1291 A arqueobotânica no Castro de Guifões (Matosinhos, Noroeste de Portugal): O primeiro estudo carpológico

Luís Seabra / Andreia Arezes / Catarina Magalhães / José Varela / João Pedro Tereso 
1305 Um Horreum Augustano na Foz do Douro (Monte do Castelo de Gaia, Vila Nova de Gaia) Rui Ramos

1311 Ponderais romanos na Lusitânia: padrões, formas, materiais e contextos de utilização Diego Barrios Rodríguez

1323 Um almofariz centro-itálico na foz do Mondego

Marco Penajoia

1335 Estruturas romanas de Carnide - Lisboa Luísa Batalha / Mário Monteiro / Guilherme Cardoso

1347 O contexto funerário do sector da "necrópole NO" da Rua das Portas de S. Antão (Lisboa): o espaço, os artefactos, os indivíduos e a sua interconectividade na interpretação do passado Sílvia Loja, José Carlos Quaresma, Nelson Cabaço, Marina Lourenço, Sílvia Casimiro, Rodrigo Banha da Silva, Francisca Alves-Cardoso

${ }_{1361}$ Povoamento em época Romana na Amadora - resultados de um projeto pluridisciplinar Gisela Encarnação / Vanessa Dias

1371 A Arquitectura Residencial em Mirobriga (Santiago do Cacém): contributo a partir de um estudo de caso Filipe Sousa / Catarina Felício

${ }_{1385}$ O fim do ciclo. Saneamento e gestão de resíduos nos edifícios termais de Mirobriga (Santiago do Cacém)

Catarina Felício / Filipe Sousa

1399 Balsa, Topografia e Urbanismo de uma Cidade Portuária Vítor Silva Dias / João Pedro Bernardes / Celso Candeias / Cristina Tété Garcia

1413 No Largo das Mouras Velhas em Faro (2017): novas evidências da necrópole norte de Ossonoba e da sua ocupação medieval Ricardo Costeira da Silva / Paulo Botelho / Fernando Santos / Liliana Nunes

1429 Instrumentos de pesca recuperados numa fábrica de salga em Ossonoba (Faro) Inês Rasteiro / Ricardo Costeira da Silva / Paulo Botelho

1439 A Necrópole Romana do Eirô, Duas Igrejas (Penafiel): intervenção arqueológica de 2016 Laura Sousa / Teresa Soeiro

1457 Ritual, descarte ou afetividade? A presença de Canis lupus familiaris na Necrópole Noroeste de Olisipo (Lisboa)

Beatriz Calapez Santos / Sofia Simões Pereira / Rodrigo Banha da Silva / Sílvia Casimiro / Cleia Detry / Francisca Alves Cardoso

1467 Dinâmicas económicas em Bracara na Antiguidade Tardia Diego Machado / Manuela Martins / Fernanda Magalhães / Natália Botica

1479 Cerâmicas e Vidros da Antiguidade Tardia do Edifício sob a Igreja do Bom Jesus (Vila Nova de Gaia) Joaquim Filipe Ramos

1493 Novos contributos para a topografia histórica de Mértola no período romano e na Antiguidade Tardia Virgílio Lopes

\section{8. Época Medieval}

1511 Cerâmicas islâmicas no Garb setentrional "português": algumas evidências e incógnitas Constança dos Santos / Helena Catarino / Susana Gómez / Maria José Gonçalves / Isabel Inácio / Gonçalo Lopes / Jacinta Bugalhão / Sandra Cavaco / Jaquelina Covaneiro / Isabel Cristina Fernandes / Ana Sofia Gomes 
1525 Contributo para o conhecimento da cosmética islâmica, em Silves, durante a Idade Média Rosa Varela Gomes

1537 Yábura e o seu território - uma análise histórico-arqueológica de Évora entre os séculos VIII-XII José Rui Santos

1547 A encosta sul do Castelo de Palmela - resultados preliminares da escavação arqueológica Luís Filipe Pereira / Michelle Teixeira Santos

1559 A igreja de São Lourenço (Mouraria, Lisboa): um conjunto de silos e de cerâmica medieval islâmica

Andreia Filipa Moreira Rodrigues

1571 O registo material de movimentações populacionais no Médio Tejo, durante os séculos XII-XIII. Dois casos de "sunken featured buildings", nos concelhos de Cartaxo e Torres Novas Marco Liberato / Helena Santos / Nuno Santos

1585 O nordeste transmontano nos alvores da Idade média. Notas para reflexão Ana Maria da Costa Oliveira

1601 Sepulturas escavadas na rocha do Norte de Portugal e do Vale do Douro: primeiros resultados do Projecto SER-NPVD

Mário Jorge Barroca / César Guedes / Andreia Arezes / Ana Maria Oliveira

1619 "Portucalem Castrum Novum" entre o Mediterrâneo e o Atlântico: o estudo dos materiais cerâmicos alto-medievais do arqueossítio da rua de D. Hugo, nํ. 5 (Porto) João Luís Veloso

1627 A Alta Idade Média na fronteira de Lafões: notas preliminares sobre a Arqueologia no Concelho de Vouzela

Manuel Luís Real / Catarina Tente

1641 Um conjunto cerâmico medieval fora de portas: um breve testemunho aveirense Susana Temudo

${ }_{1651}$ Os Lóios do Porto: uma perspetiva integrada no panorama funerário da Baixa Idade Média à Época Moderna em meios urbanos em Portugal

Ana Lema Seabra

1659 O Caminho Português Interior de Santiago como eixo viário na Idade Média Pedro Azevedo

1665 Morfologia Urbana: Um exercício em torno do Castelo de Ourém André Donas-Botto / Jaqueline Pereira

1677 Intervenção arqueológica na Rua Marquês de Pombal/Largo do Espírito Santo (Bucelas, Loures)

Florbela Estêvão / Nathalie Antunes-Ferreira / Dário Ramos Neves / Inês Lisboa

1691 O Cemitério Medieval do Poço do Borratém e a espacialidade funerária na cidade de Lisboa Inês Belém / Vanessa Filipe / Vasco Noronha Vieira / Sónia Ferro / Rodrigo Banha da Silva

1705 Um Espaço Funerário Conventual do séc. XV em Lisboa: o caso do Convento de São Domingos da Cidade Sérgio Pedroso / Sílvia Casimiro / Rodrigo Banha da Silva / Francisca Alves Cardoso

\section{9. Época Moderna e Contemporânea}

1721 Arqueologia Moderna em Portugal: algumas reflexões críticas em torno da quantificação de conjuntos cerâmicos e suas inferências históricas e antropológicas Rodrigo Banha da Silva / André Bargão / Sara da Cruz Ferreira

1733 Faianças de dois contextos entre os finais do século XVI e XVIII do Palácio dos Condes de Penafiel, Lisboa

Martim Lopes / Tomás Mesquita 
1747 Um perfil de consumo do século XVIII na foz do Tejo: O caso do Mercado da Ribeira, Lisboa Sara da Cruz Ferreira / Rodrigo Banha da Silva / André Bargão

1761 Os Cachimbos dos Séculos XVII e XVIII do Palácio Mesquitela e Convento dos Inglesinhos (Lisboa)

Inês Simão / Marina Pinto / João Pimenta / Sara da Cruz Ferreira / André Bargão / Rodrigo Banha da Silva

1775 "Tomar os fumos da erua que chamão em Portugal erua sancta». Estudo de Cachimbos provenientes da Rua do Terreiro do Trigo, Lisboa

Miguel Martins de Sousa / José Pedro Henriques / Vanessa Galiza Filipe

1787 Cachimbos de Barro Caulínitico da Sé da Cidade Velha (República de Cabo Verde)

Rodrigo Banha da Silva / João Pimenta / Clementino Amaro

1801 Algumas considerações sobre espólio não cerâmico recuperado no Largo de Jesus (Lisboa) Carlos Boavida

1815 Adereços de vidro, dos séculos XVI-XVIII, procedentes do antigo Convento de Santana de Lisboa (anéis, braceletes e contas)

Joana Gonçalves / Rosa Varela Gomes / Mário Varela Gomes

1837 Da ostentação, luxo e poder à simplicidade do uso quotidiano: arqueologia e simbologia de joias e adornos da Idade Moderna Portuguesa Jéssica Iglésias

1849 Os amuletos em Portugal - dos objetos às superstições: o coral vermelho Alexandra Vieira

1865 Cerâmicas de Vila Franca de Xira nos séculos XV e XVI Eva Pires

1879 «Não passa por teu o que me pertence». Marcas de individualização associadas a faianças do Convento de Nossa Senhora de Aracoeli, Alcácer do Sal Catarina Parreira / Íris Fragoso / Miguel Martins de Sousa

1891 Cerâmica de Leiria: alguns focos de produção

Jaqueline Pereira / André Donas-Botto

1901 Os Fornos na Rua da Biquinha, em Óbidos Hugo Silva / Filipe Oliveira

1909 A casa de Pêro Fernandes, contador dos contos de D. Manuel I: o sítio arqueológico da Silha do Alferes, Seixal (século XVI) Mariana Nunes Ferreira

1921 O Alto da Vigia (Sintra) e a vigilância e defesa da costa Alexandre Gonçalves / Sandra Santos

1937 O contexto da torre sineira da Igreja de Santa Maria de Loures Paulo Calaveira / Martim Lopes

1949 A Necrópole do Hospital Militar do Castelo de São Jorge e as práticas funerárias na Lisboa de Época Moderna Susana Henriques / Liliana Matias de Carvalho / Ana Amarante / Sofia N. Wasterlain

1963 SAND - Sarilhos Grandes Entre dois Mundos: o adro da Igreja e a Paleobiologia dos ossos humanos recuperados

Paula Alves Pereira / Roger Lee Jesus / Bruno M. Magalhães

1975 Expansão urbana da vila de Cascais no século XVII e XVIII: a intervenção arqueológica na Rua da Vitória no 15 a 17

Tiago Pereira / Vanessa Filipe

1987 Novos dados para o conhecimento do Urbanismo de Faro em época Moderna Ana Rosa 
1995 Um exemplo de Arqueologia Urbana em Alcoutim: o Antigo Edifício dos CTT Marco Fernandes / Marta Dias / Alexandra Gradim / Virgílio Lopes / Susana Gómez Martínez

2007 Palácio dos Ferrazes (Rua das Flores/Rua da Vitória, Porto): a cocheira de Domingos Oliveira Maia

Francisco Raimundo

2021 As muitas vidas de um edifício urbano: História, Arqueologia e Antropologia no antigo Recreatório Paroquial de Penafiel Helena Bernardo / Jorge Sampaio / Marta Borges

2035 O convento de Nossa Senhora da Esperança de Ponta Delgada: o contributo da arqueologia para o conhecimento de um monumento identitário João Gonçalves Araújo / N’Zinga Oliveira

2047 Arqueologia na ilha do Corvo... em busca da capela de Nossa Senhora do Rosário Tânia Manuel Casimiro / José Luís Neto / Luís Borges / Pedro Parreira

2059 Perdidos à vista da Costa. Trabalhos arqueológicos subaquáticos na Barra do Tejo Jorge Freire / José Bettencourt / Augusto Salgado

2071 Arqueologia marítima em Cabo Verde: enquadramento e primeiros resultados do projecto CONCHA

José Bettencourt / Adilson Dias / Carlos Lima / Christelle Chouzenoux / Cristóvão Fonseca / Dúnia Pereira / Gonçalo Lopes / Inês Coelho / Jaylson Monteiro / José Lima / Maria Eugénia Alves / Patrícia Carvalho / Tiago Silva

2085 Trabalhos arqueológicos na Cidade Velha (Ribeira Grande de Santiago, Cabo Verde): reflexões sobre um projecto de investigação e divulgação patrimonial André Teixeira / Jaylson Monteiro / Mariana Mateus / Nireide Tavares / Cristovão Fonseca / Gonçalo C. Lopes / Joana Bento Torres / Dúnia Pereira / André Bargão / Aurélie Mayer / Bruno Zélie / Carlos Lima / Christelle Chouzenoux / Inês Henriques / Inês Pinto Coelho / José Lima / Patrícia Carvalho / Tiago Silva

2103 A antiga fortificação de Quelba / Khor Kalba (E.A.U.). Resultados de quatro campanhas de escavações, problemáticas e perspectivas futuras Rui Carita / Rosa Varela Gomes / Mário Varela Gomes / Kamyar Kamyad

2123 Colónias para homens novos: arqueologia da colonização agrária fascista no noroeste ibérico Xurxo Ayán Vila / José Mạ . Señorán Martín 


\title{
DO SÍTIO ARQUEOLÓGICO AO MUSEU: UM PERCURSO (TAMBÉM) DIDÁTICO
}

\author{
Lídia Fernandes ${ }^{1}$
}

\begin{abstract}
RESUMO
Qualquer sítio arqueológico, per si, permite questionar o sentido da arqueologia enquanto ciência que "produz" ruína. O conhecimento histórico, no que respeita à arqueologia, passa inevitavelmente pela consequente atuação em relação a tais estruturas que, musealizadas ou deixadas ao abandono, são testemunhas da memória histórica. A abordagem que atualmente se realiza é muito diversa consoante o objeto arqueológico em causa, o seu contexto ou o protagonismo que se pretende. Com efeito, a musealização de sítios arqueológicos tem, recentemente, suscitado interesses ambivalentes passando as ruínas a servir de mote a projetos icónicos que ultrapassam, em muitos casos, o objetivo para o qual foram criados. Nem tudo carece de musealização, mas tudo o que é musealizado carece, obrigatoriamente, de um enquadramento que dignifique o próprio objeto.

Palavras-chave: Estruturas arqueológicas, Musealização, Ruína, Preservação, Dinamização.
\end{abstract}

\begin{abstract}
Any archaeological site, by itself, allows to question the meaning of archaeology as a science that "produces" ruin. The historical knowledge inevitably leads to consequent action in relation to its structures, which musealized or left to abandon, are witnesses of historical memory.

The approach currently perceived is distinct according to the archaeological object in question, its context or its intended role. In fact, recently, the musealization of archaeological sites has aroused ambivalent interests, as the ruins serve as a motto for iconic projects which, in many cases, go beyond the purpose for which they were created. Not everything deserves musealization, but all that is musealized requires a dignified framework for the object itself.
\end{abstract}

Keywords: Archaeological structures, Musealization, Ruin, Conservation, Dynamization.

\section{INTRODUÇÃO}

A musealização de locais arqueológicos em Portugal constitui uma problemática de contornos indefinidos. Os sítios arqueológicos detêm uma posição secundária e ambivalente situando-se entre o que se considera um espaço museológico - por vezes diretamente relacionado com um museu - e áreas de recreio/passeio, sem que aquela perspetiva de entendimento se aplique, na maior parte dos casos, a esta última situação.

A dificuldade na leitura das estruturas, a ausência de suportes explicativos ou o afastamento dos sítios relativamente aos centros urbanos, tem suscitado dificuldades num correto e adequado usufruir destes espaços, verdadeiros locais de conhecimento que permitem alcançar múltiplos objetivos pedagó- gicos. Permanecemos, hoje, sem uma política de dinamização verdadeiramente instituída e instruída, sem balizas de atuação definidas dependendo, cada sítio arqueológico, da autonomia, dos recursos económicos ou da voluntariedade e dinamização das respetivas equipas de trabalho que sustentam políticas de divulgação e salvaguarda mais ou menos pertinentes e ou adequadas ou, na maior parte dos casos, as possíveis de serem implementadas.

É o próprio sítio arqueológico que possibilita questionar o sentido da arqueologia enquanto ciência que "produz" ruína, uma vez que coloca a descobertas estruturas em deficiente estado de conservação. O conhecimento histórico passa inevitavelmente pela consequente atuação em relação a tais vestígios que, musealizadas ou deixadas ao abandono, ficarão sempre como testemunhos da memória.

1. Arqueóloga. Coordenadora do Museu de Lisboa - Teatro Romano / EGEAC; lidiafernandes@egeac.pt 
A abordagem que atualmente se realiza em tais espaços é de índole muito diversa consoante o objeto arqueológico em questão, o contexto em que se insere ou, na maior parte dos casos, o protagonismo que se pretende atingir. Com efeito, e mais recentemente, a musealização destes sítios tem suscitado interesses ambivalentes passando as ruínas a servir de mote a projetos icónicos que ultrapassam, em muitos casos, o objetivo para o qual foram criados. Nem tudo carece de musealização, mas tudo o que é musealizado carece, obrigatoriamente, de um enquadramento que dignifique o próprio objeto.

$\mathrm{Na}$ breve abordagem que realizamos apresenta-se uma reflexão sobre a musealização de sítios arqueológicos e do seu entendimento enquanto espaços museais, colocando-se o acento no facto de eles próprios poderem ser perspetivados como objetos museológicos. Pelo facto de grande parte dos sítios arqueológicos abrangerem extensas áreas, possibilitam e suscitam perspetivas de visualização diversificadas a partir de pontos de observação distintos. Em muitos casos é possível percorrê-los, ao invés de os visualizar estaticamente, proporcionando uma aproximação visitante/objeto, distanciando-se da tradicional relação presente nos museus com os objetos encerrados em vitrinas.

Os sítios arqueológicos permitem, deste modo, aproximações distintas por parte do visitante e constituem, em primeira mão, uma experiência única de ensinamento e de perceção e apreensão do passado. A cultura de um local, de uma região, de um país ou território, é expressa por aquilo que se mostra num museu, ainda que o museu não represente a cultura de um país. As noções de cultura são muito mais vastas e não podem, nem devem, ser exclusivamente encerradas em edifícios dedicados à sua preservação. No entanto, esta impossibilidade de representação sublinha a tarefa primordial de cada museu: o de preservar o que expõe, o de estudar e perceber o melhor possível o que guarda e divulgar o que possui.

Outra questão a colocar é perceber se os sítios arqueológicos podem ser considerados também como espaços museais. Quando existe um na proximidade daqueles, criado em função dos vestígios identificados e destinado à sua interpretação, pensamos que tal questão é de resposta simples, pois tal equipamento apenas existe em função do sítio colocado a descoberto, destinando-se a explicá-lo e a interpretá-lo. $\mathrm{Na}$ ausência de tal equipamento - seja um museu ou centro interpretativo - a questão que colocamos é se um local arqueológico musealizado também pode ser encarado como tal, isto é, se pode ser classificado como museu. Esta questão, que justificaria um profundo debate, conduz-nos a questionar a própria classificação de muitos espaços como museu.

Por fim, coloca-se a questão de saber o que é, de facto, um "sítio musealizado", assim como perceber qual a distinção que estabelece em relação a um "sítio arqueológico musealizado" ou, simplesmente, um "sítio" ou "área arqueológica". Esta questão apresenta uma outra vertente se, na equação, adicionarmos um outro conceito: o de "ruína". Alguns sítios arqueológicos não são, de facto, mais do que isso, embora o conceito possa encerrar uma perspetiva menos negativa do que a que geralmente lhe conferimos.

\section{A RUÍNA E O SÍTIO ARQUEOLÓGICO}

Numa abordagem imediata estes dois conceitos são distintos. Na verdade, uma ruína pode não ser um sítio arqueológico, mas raras vezes um sítio arqueológico não é ruína. Abstemo-nos quase sempre de empregar o termo "ruína" pois, de imediato, a sua carga negativa leva a considerar um sítio arqueológico como uma derrota, algo que já não serve o seu original propósito ou outro qualquer. No entanto, estamos rodeados por ruínas e não precisam de ser arqueológicas para o serem.

$\mathrm{Na}$ verdade, há algo de profundamente verdadeiro nas ruínas. Elas são, pela sua própria condição, garantes de autenticidade e integridade. Também, na maior parte dos casos, não sofreram restauros posteriores, intencionalmente realizados com o objetivo de as tornar "não ruínas". O ponto unificador é o de serem estruturas arquitetónicas e o facto de ser devido à ação humana, ou à sua ausência, que se deu a sua grande transformação. A ruína é afinal "o paradigma do incompleto" (Pérez-Prat Durbán, 2018, 91).

O conceito de "ruína", embora não tenha sido alvo de uma definição jurídica deveria, segundo alguns autores, ser regulada de forma a salvaguardar quer a sua manutenção, bem como o seu acesso (veja-se a este propósito, o texto de Pérez-Prat Durbán, 2018, 89-101). No entanto, há uma substancial diferença entre "ruína" e "ruína cultural" e é precisamente este último aspeto que nos interessa ${ }^{2}$.

2. Ainda assim, nem esta última distinção é pacífica e uma ruína que não é considerada cultural pode, a partir de dada altura, passar a sê-lo. 
Algo que todas as ruínas têm em comum e que as distingue da maioria dos objetos dentro de um museu, é o facto de terem um contexto, o seu contexto. É algo que não foi deslocado e no qual o seu entorno, embora se possa ter modificado ao longo dos tempos, continua a ser o seu e tem uma história. É este o aspeto a sublinhar, é esta a premissa da qual se deve partir, e é isto que não se encontra num museu pois os seus objetos são sempre deslocados. Uma ruína ou um sítio arqueológico são eles próprios e o seu contexto e não existem um sem o outro. Esta razão, além de outras, leva a aproximar um sítio arqueológico a uma ruína. A diferença estabelece-se bem mais no nosso imaginário do que propriamente numa distinção concetual do objeto em causa.

Quando falamos de ruína, invocamos o contributo dos arquitetos do renascimento ou os do séc. XVIII, os registos magníficos dos desenhos de Piranesi onde as ruínas e a vegetação fazem parte de um mesmo ser vivo, ou os contributos do séc. XIX, como os de Alexandre Laborde onde os seus desenhos são tão mais explícitos que os textos. É impossível empregar a designação de "ruína" sem que tal carga histórica lhe esteja associada e será ela - por um intencional distanciamento com a experiência do passado - que nos leva a preterir o termo.

Hoje em dia queremos sublinhar a ideia de que um sítio arqueológico é o produto de uma intencional ação humana, a descoberta de algo até então escondido. No entanto, são mais os casos em que os sítios arqueológicos são também ruína do que aqueles em que tal não se verifica. A nosso ver, ruína e sítio arqueológico não são precisamente a mesma coisa, embora tenham inúmeros pontos de contacto, e haverá benefícios se o conceito de "ruína" for legislado, concedendo algum grau de proteção às estruturas, arqueológicas ou não, que não se encontram conservadas, musealizadas ou restauradas ${ }^{3}$. Como refere Pedro Cardim "Sendo património arqueológico um conceito distinto do de ruína, integrará e afirmará distinto significado. Efectivamente, à obra patrimonial atribui-se um valor não só material como simbólico. A ruína enquanto não é reconhecida como valor patrimonial, apenas aguarda que a reabilitem ou substituam..." $(2018,8)$.

3. A Lista do Património Mundial da UNESCO, por exemplo, não reconhece este termo embora “... las ruínas podriam llegar a abarcar cerca del veinte por ciento de los lás de mil bienes inscritos" (Pérez-Prat Durbán, 2018, 89).

\section{SÍTIO ARQUEOLÓGICO VERSUS SÍTIO MUSEALIZADO}

Na verdade, quando pensamos na Acrópole de Atenas, ou na cidade romana de Dougga, na Tunísia, não nos ocorre classificar tais sítios como "museu" ou designá-los por "sítios musealizados". Museus e sítios musealizadas têm um significado distinto que, embora não se estabeleça uma evidente diferença, não são confundíveis. Designamo-los, como tantos outros, por sítios arqueológicos, mas não por sítios musealizados.

A distinção entre aqueles dois conceitos impõe-se, uma vez que, embora um sítio musealizado possa ser arqueológico nem todos os sítios musealizados são sítios arqueológicos. A primeira grande distinção estabelece-se com os sítios históricos. Um castelo medieval, um forte do séc. XVI, uma casa senhorial do séc. XVIII, ou uma casa rural do séc. XX podem não ser sítios arqueológicos, pois não foram descobertos sob o solo e o seu bom estado de conservação ao longo dos tempos foi o garante da sua manutenção até à atualidade. Mesmo a classificação de "sítio arqueológico" não é clara. $\mathrm{Na}$ verdade, podemos considerar como tal, qualquer local, ou sítio específico onde se registam vestígios da atividade humana. Aproximamo-nos, assim, do conceito amplo e geral de Paul Bahn (1996, p. 70), ainda que outras perspetivas possam ser aceites, como o caso de àreas com limites definidos, ou um sítio descontínuo que preserva testemunhos da ação humana os quais podem ser colocados a descoberto por ação da arqueologia (Feder, 1997) ou, de forma ainda mais circunscrita, sítios, "locais onde são identificados mais materiais arqueológicos que na paisagem envolvente" (Carman, 1999, p. 23).

Estes conceitos, no entanto, não têm aplicabilidade em variadissimos casos, epecialmente no que à arqueologia urbana diz respeito, uma vez que muitas cidades com um passado histórico recuado, albergam no seu interior um contínuo de estruturas e materiais arqueológicos impedindo, assim, a delimitação de áreas onde tais vestígios surgem. Nestes casos, como acontece em Lisboa, a inexistência de áreas sem sítios arqueológicos corresponde, afinal, a áreas ainda não intervencionadas ou, em muitos casos, de sítios arqueológicos que já não o são, pela sua escavação e consequente destruição, termo ao qual se substitui o de "desmontagem”, a bem de descanso de algumas consciências e 
como se tal não fosse sinónimo, no que respeita ao universo arqueológico.

Numa outra perspetiva, a distinção entre "sítio arqueológico" e "sítio musealizado" introduz-nos no conceito de "museu comunitário", definido em 1979 por Hugues de Varine, inaugurando a distinção entre museu dito tradicional e museu comunitário. Não deixando de sublinhar a relevância do conceito (tema que retomaremos), especialmente aquando da sua introdução, dificilmente o poderíamos aplicar no âmbito de muitos sítios arqueológicos e até de alguns museus.

Em alguns casos e cada vez mais, os sítios arqueológicos e sítios musealizados podem não nascer de uma exigência social da comunidade. Neste sentido, não correspondem a qualquer tipo de "museu comunitário", não sendo criados pela necessidade de partilha de um passado comum ou de algo que polarize a noção de identidade ou enraizamento de uma memória conjunta.

Não raras vezes, quer no passado ou também no presente $^{4}$, o nascimento ou a criação de sítios arqueológicos é fruto de uma legislação específica de salvaguarda dos bens culturais e bens arqueológicos, assim como, e especialmente, do tipo de intervenção fisica que se realiza em determinado país, seguindo legislação internacional estabelecida. Veja-se o caso do Núclo Arqueológico da Rua dos Correeiros ou o das estruturas arqueológicas conservadas no atual Hotel Eurostars Museum, em Lisboa. Em ambos os casos foi uma decisão entre a tutela que gere o património arqueológico português e o dono de obra, que tornou possível a manutenção das estruturas arqueológicas e a sua respetiva musealização, a qual ficou, no que respeita aos custos envolvidos, a cargo dos respetivos proprietários (Figura 1).

Falamos também de sítios onde a decisão da manutenção das estruturas à vista e da promoção da sua visualização e visitação não é recente, antes tomada há muito tempo, perdurando até à atualidade, tentando-se em alguns casos uma atualização das condições de visita, limpeza e manutenção das estruturas arqueológicas, como o caso do Castro de Vila Nova de S. Pedro, mais recentemente alvo de novas campanhas de escavação no âmbito de um projecto

4. Especialmente no presente devido, apenas e tão somente, ao maior número de intervenções arqueológicas realizadas. que envolveu várias instituições ${ }^{5}$. Inserido neste contexto iniciativas como o "Dia Aberto" à comunidade e demais visitantes, com visitas guiadas e ateliers de arqueologia experimental. Não obstante, o sítio não oferece informação detalhada e as muitas peças recolhidas desde o séc. XIX, quando o local foi escavado por Afonso do Paço, encontram-se no Museu Municipal de Torres Vedras e no Museu do Carmo, em Lisboa, sem que exista qualquer menção ao facto no próprio local.

Também neste caso, a autarquia procura uma regularização da posse dos terrenos, tendo estado em cima da mesa várias soluções como o da sua expropriação ou o pagamento de aluguer uma vez que os terrenos são privados e a continuação da escavação do sítio mais não fará que alargar a área de propriedade privada a ser afetada.

São pois situações herdadas do passado, não raras vezes suscitando grandes problemas de foro administrativo, especialmente relacionados com a propriedade dos terrenos onde os sítios arqueológicos se localizam. Veja-se o caso paradigmático da antiga cidade de Balsa, próximo de Luz de Tavira.

Infelizmente, são raros os casos onde o desejo coletivo de transformar um sítio arqueológico num sítio visitável e musealizado ocorre. Ainda que tal possa acontecer, não significa que o sentido de pertença seja universal. A área arqueológica do Freixo ou o sítio do Castelo Velho, em Freixo de Numão, por exemplo, são casos onde a salvaguarda foi, no embrião dos projetos, consensual na comunidade científica ainda que à margem da comunidade local.

Em muitos casos, a musealização de um sítio arqueológico não é, sequer, especialmente acarinhada pela comunidade próxima, a qual lhe é praticamente indiferente, ainda que se imponha quando, progressiva e lentamente, essa comunidade vai percebendo o valor patrimonial em causa. É neste preciso campo que gostariamos de centrar a questão. A ausência de um investimento por parte da tutela, quer na salvaguarda e proteção de um sítio arqueológico, quer especialmente no seu conhecimento e divulgação diretamente relacionada com o da sua musealização

\footnotetext{
5. Equipa de arqueólogos da Associação dos Arqueólogos Portugueses, da Faculdade de Letras da Universidade de Lisboa, com o apoio da Fundação para Ciência e Tecnologia, da Câmara Municipal da Azambuja e da União das Freguesias de Manique do Intendente, Vila Nova de São Pedro e Maçussa.
} 
- é a responsável por um processo autofágico onde nem a população nem os investidores, públicos ou privados, perspetivam os benefícios de defender e criar sítios musealizados nos seus territórios.

Naturalmente que esta responsabilidade caberá aos organismos estatais competentes, mas uma sociedade não se pode limitar à iniciativa pública nem a um papel por parte do estado que determine as suas opções culturais, especialmente quando estas representam a essência de um povo ou de uma determinada população, quando estão em causa valores civilizacionais determinantes que possibilitem o entendimento de uma sociedade, de uma região ou de um local, através dos vestígios culturais por ela deixados.

Outros intervenientes podem e devem entrar em cena promovendo objetivos, que não apenas os enunciados, que influnciem o destino de um sítio arqueológico.

A partir do momento em que a presença de locais arqueológicos confere um sentido diferencial a sítios que, à partida, seriam iguais a muitos outros, promovem-se fatores como a surpresa, o inusitado, a singularidade mas também o conhecimento, a partilha, o património, a cultura, valores que se tornam, em si mesmos, uma mais-valia.

O caso relativamente recente de unidades hoteleiras onde a presença de estruturas arqueológicas, colocadas a descoberto no decorrer das obras de construção ou de reconversão de antigos edifícios, tem suscitado, mediante um adequado enquadramento arquitetónico, um motivo diferenciador, constitui um exemplo por demais evidente. Confere-se assim um novo sentido à justificativa museológica, como no caso do Corpo Santo Lisbon Historical Hotel, em Lisboa, onde um troço de cerca de $30 \mathrm{~m}$ da Muralha Fernandina, além de outros vestígios ${ }^{6}$, foram identificados, sendo preservados e integrados nas áreas públicas da instalação hoteleira.

Não queremos com isto dizer que não concordamos com tal procedimento. Muito pelo contrário, uma vez que este será um dos casos onde os objetivos justificam os meios. No entanto, esse fim, que pode ser justificável por parte do promotor, não poderá nunca ser o que subjaz a quem decide pela conservação ou não das estruturas e pela sua transformação de sítio arqueológico num sítio arqueológico musealizado.

6. Além de muitos outros vestígios, como a Torre de João Bretão e o Palácio dos Côrte-Real.
Em contexto urbano estas questões são ainda mais difíceis de equacionar. Nestes casos, apesar de a decisão não depender de um só interlecutor, não pode ser a comunidade a decidir uma vez que não detém o real e mais informado conhecimento técnico sobre os vestígios em questão. Serão sim os decisores políticos baseados, naturalmente, em pareceres técnicos válidos, fundamentados e esclarecidos que devem prevalecer. Outros casos há, no entanto, que é o interesse da comunidade que obriga a classe política a optar pela manutenção de algo, quando o que está em causa é particularmente relevante para a comunidade local. Veja-se o caso, por exemplo, do museu ao ar livre Beamish Museum, Inglaterra, no condado de Durham. Independentemente de gostarmos ou não do conceito de museu subjacente, e sem que exista algo verdadeiramente patrimonial a defender, este museu só existe pelo contributo e trabalho da comunidade, assim como pelo financiamento exclusivo das instituições da região7.

Mesmo neste caso, ou especialmente noutros, tais situações só são possíveis de alcançar quando é a investigação que subjaz e sustenta eventuais decisões políticas. Tudo o que vem depois, respeitante ao futuro do sítio arqueológico e/ou eventual sítio musealizado, só poderá ser alvo de tais transformações se a investigação sustentar as decisões políticas e económicas concernentes à criação de tais sítios.

\section{O QUE SIGNIFICA MUSEALIZAR?}

Musealizar é, literalmente tornar museu. A palavra "museu" provém do grego, significando os templos ou santuários onde as musas, filhas de Zeus e Mnemósine, habitavam. O termo significa também a biblioteca ou espaço criativo, pois era o local dedicado à música e às artes. Museu é, deste modo, sinónimo de casa e memória, de criação e resguardo. E não se pode, ontem como hoje, dissociar estas duas vertentes do conceito de museu: a proteção do passado e da memória, mas também o da sua reani-

7. Trata-se de um museu, criado na década de 1970, que procura recriar de foma mais fidedigna possível, o tipo de vida de uma pequena povoação dos inícios do séc. XX, tendo sido construídos vários equipamentos típicos da época, como restaurantes, lojas, armazéns, tipografia, dentista, banco, padaria, fábrica de doces, cafés, lojas e casas particulares diversas. Em muitos casos os objetos foram oferecidos pela comunidade local. O bilhete de entrada permite visitar, durante um ano inteiro, o museu ao ar livre. 
mação e interpretação. Fazer prevalecer uma destas componentes corresponde a truncar a essência de um museu no seu completo e correto significado e entendimento.

"Tornar museu" pode, no entanto, suscitar um sentido negativo do conceito, que aproximaríamos à ideia de "congelar no tempo" ou eternizar algo que já não vive.

Um local musealizado, seja arqueológico ou não, é um espaço que é tratado como tradicionalmente se tratam as peças de um museu: há um caminho direto para chegar até elas, através de sinalética específica que encaminha o visitante; estão identificadas, através de uma legenda que nos diz o que é o objeto, de que material é feito e quando foi produzido; podem estar associadas outras informações, como textos, mais ou menos longos, que nos integrem no âmbito cultural ou cronológico sobre determinado objeto; mapas, desenhos de reconstituição, filmes, maquetas, etc, etc. O objetivo é sempre o mesmo: a identificação do objeto, a explicitação da sua origem e formas de produção/fabrico, a sua função e as razões subjacentes à criação.

Assim, uma das explicações do que é um sítio musealizado leva a equiparar um objeto em exposição num museu e numa vitrina, ou outro suporte, com o objeto "sítio construído" que se pretende mostrar. Em ambos os casos, existe uma explicação do que é, independentemente do grau de pormenor ou da quantidade de informação fornecida.

Naturalmente que existem diferenças entre o tipo e quantidade de informação que se fornece sobre peças num museu e a que se disponibiliza num sítio arqueológico que ocupa largos metros quadrados. Em ambos os casos, a informação em demasia também pode ser antagónica ao objetivo pretendido. Não obstante, será sempre preferível fornecer mais e melhor informação do que nada ter que explique uma edificação que, pelo seu estado de "ruína", pode ser parcamente ilustrativa. Mesmo em bom estado de conservação, tal como ocorre com monumentos que vemos ou visitamos, por vezes ainda em funcionamento, desconhecemos, em variadíssimos casos, respostas às muitas questões que cada um deles nos pode suscitar: o que é, qual a função, quando e como foi construído.

Vários níveis de informação, quando fornecidos separadamente, quer se trate de peças em museu, quer de sítios arqueológicos, são sempre a melhor opção uma vez que suscitam e possibilitam a escolha, não obrigando à respetiva leitura/visualização ${ }^{8}$. Deste modo, disponibiliza-se ao visitante várias possibilidades de informação, que variam entre o grau e quantidade de conteúdos que o próprio pretenda, a cada momento, visualizar e rececionar, ao longo da visita que realiza. Neste âmbito, damos o exemplo do Parque Arqueológico Cerro del Molinete, em Cartagena (Espanha), onde suportes digitais, com plantas e reconstituições das várias estruturas arqueológicas convivem, lado a lado, com informações impressas em suportes rígidos, de caráter mais tradicional (Figuras. 2 e 3 ).

Outro exemplo é-nos oferecido pelos subterrâneos do Museu d'Historia de Barcelona-MUHBA. Nestes dois casos a quantidade e tipo de informação fornecida é totalmente distinta. No primeiro, assistimos a uma pormenorização de conteúdos, complementados por audioguias, onde desenhos, reconstituições e descrição escrita é acompanhada por imagens digitais, sendo disponibilizada mais informação. No segundo caso, os dados fornecidos são em muito menor escala, encontrando-se remetidos para explicações mais generalistas em "textos de sala" destacados em pontos precisos do percurso (Figura 4). Pontualmente, e de forma muito simples, é disponibilizada em locais específicos alguma informação. Algumas peças são expostas com uma descrição sumária. São, diríamos, chamadas de atenção pontuais que animam o percurso e retêm o olhar de quem passa, enriquecendo a informação visual dada pelas estruturas aqrueológicas.

Dois casos muito distintos que refletem objetivos diferenciados e adaptados a distintas situações. Em Barcelona o volume de visitantes será substancialmente maior que em Cartagena, sendo que aqui o percurso pedonal ao longo das estruturas arqueológicas, realiza-se num nível fisicamente mais elevado, um mezanino largo, existindo a possibilidade de descer ao nível dos vestígios, onde a informação é bem mais sucinta.

\footnotetext{
8. Em tempos realizei um curso de formação que tratava da qualidade e quantidade de informações que um museu deveria ter. Dizia a formadora que, se toda a informação escrita num museu demorasse mais de 1 hora a ler era um erro pois o tempo máximo de concentração do ser humano não ultrapassa tal período. Em nossa opinião, tais generalizações são inteiramente incorretas. Pessoalmente já me ocorreu ficar 30 minutos num museu sem intenção de regressar e, em outros casos, aí me de demorar 5 horas com vontade de prolongar a visita.
} 
Distintas soluções, diferentes níveis de informação, adequada, sempre, aos espaços em questão e aos distintos públicos que se pretende informar. Não existem receitas imutáveis, nem soluções estereotipadas para todos os casos. Os locais são sempre diferentes e é sempre distinto o público que os visita. Não obstante esta ausência de linhas reguladoras ou orientadoras, a presença de informação fundamentada e fidedigna constitui o ponto de partida, o único válido aliás, para um trabalho consequente do ponto de vista de utilizar da melhor forma possível os recursos disponíveis.

Por vezes, os sítios arqueológicos transformam-se em ícones, o que pode ocorrer pela relevância dos vestígios, mas também, e especialmente nos últimos tempos, quando os projetos de arquitetura, destinados à sua proteção, se tornam nos verdadeiros ícones.

O caso paradigmático das termas de Vals, na Suiça, com projeto de arquitetura de Peter Zumthor, trouxe à ribalta as termas romanas aí existentes. $\mathrm{O}$ mesmo aconteceu com o edifício de proteção das estruturas de abrigo, de cronologia romana, em Chur (Graubunden, nos Alpes suiços). Em ambos os casos, são os projetos arquitetónicos bem mais conhecidos no mundo da arquitetura do que da arqueologia. Ambos da década de 1980, não deixam de ter presente a primordial relevância do objetivo a cumprir. Outros há em que tal objetivo se perde perante o inusitado do projeto arquitetural, figurando este como o ponto fulcral da visita ao local, sobrepondo-se ao objeto alvo do projeto. Veja-se o caso, por exemplo do complexo conhecido por "Las Setas", designação dada popularmente ao Metropol Parasol, construído no centro de Sevilha, na Plaza de la Encarnación, com projeto do arquiteto Jürgen Hermann (Figura 5).

Neste último caso o sítio arqueológico constitui mais um pólo de atração no conjunto de várias valências que se congregam no espaço.

Nem sempre, no entanto, é possível ou aconselhável enveredar por projetos de arquitetura icónicos, sensacionalistas ou grandiosos. Por um lado porque, simplesmente, não são necessários, por outro porque o mais sensato é abraçar uma integração dos vestígios arqueológicos adequado ao espaço onde surgem e optar pela potenciação de verbas para a sua conservação, estudo e divulgação. Veja-se, a este propósito, o caso da estação de combóios de Braga, onde a modesta integração arquitetónica dos vestígios arqueológicos dos banhos pré-romanos, com adequada infor- mação, constitui o suficiente para a sua salvaguarda e correta disponibilização de informação9.

E este tema sugere-nos, naturalmente, o da função social da musealização das estruturas arqueológicas e, afinal, a própria função social da arqueologia.

\section{A FUNÇÃO SOCIAL DA ARQUEOLOGIA E DOS SÍTIOS ARQUEOLÓGICOS}

É uma verdade absoluta que, se a arqueologia não conta uma história não serve para nada. O ideal é servir para contar muitas história e, através delas, múltiplas perspetivas, pois a história não tem um sentido único, um princípio, um meio e um fim. A história tem factos, tem datas mas é feita de pessoas que a fazem e, deste modo, nunca é línear, simples ou unidirecional. A ideia defendida de que a sociedade, território e objeto se encontrem em espaços como museus, os tais "museus comunitários", definindo-os na sua essência, poderá constituir uma aspiração ou até um sucesso, em alguns casos, mas está claramente afastada na grande maioria deles.

Quando falamos de musealização de sítios arqueológicos falamos de partilhar estruturas arqueológicas que se encontram in situ, não tendo sido pré-determinado que tais vestígios se localizassem num determinado local. Se musealizar significa, a par de outras vertentes, tornar museu, não é obrigatóio pensarmos que falamos de espaços criados pela comunidade, aproximando-nos do ideal de "museu comunitário" definido por Hugues de Varine (200o). Como vimos, a trilogia "sociedade, território e objeto", não tem de estar presente e há sítios musealizados que cumprem um papel crucial sem que tenham sido desejados pela comunidade ou tido a sua participação ou colaboração direta.

\section{O CASO DO TEATRO ROMANO DE LISBOA}

O exemplo do teatro romano de Lisboa é paradigmático do que expusemos.

Descobertas as suas ruínas no longínquo ano de 1798, na sequência da reconstrução da cidade após a catástrofe de 1755, a manutenção a descoberto das mesmas não viria a ser concretizada devido ao con-

9. Em 2007, quando conhecemos o local coincidiu deparamo-nos com uma turma de crianças do ensino básico que faziam uma visita. 
turbado período político que o país atravessava, com a invasão napoleónica em 1807 e a consequente fuga da família real para o Brasil. Tal contexto impediu a concretização da ideia do arquiteto italiano Francisco Xavier Fabri - responsável por parte do trabalhos de exumação dos vestígios, embora não do seu descobrimento ${ }^{10}$ - que pugnava pela manutenção à vista daquelas ruínas.

Remonta a este período e àquele arquiteto, a ideia precoce da musealização das estruturas, preconizando a continuação dos trabalhos de escavação, inclusivamente a compra de novos terrenos, a proteção dos vestígios com a delimitação da área por eles abarcada e construção de um muro que protegesse $o$ local e, por fim, o "restauro" das estruturas através da recolocação dos vestígios no seu lugar original ${ }^{11}$. Temos assim, um precoce entendimento de musealização nos finais do séc. XVIII em Portugal. Curioso é o facto do arquiteto explicitar as vantagens do processo: o de mostrar a antiguidade e relevância das estruturas, “... como coiza útil e necessária, pela singularidade do Monumento, que merece todo o empenho de se dar ao Publico com a maior exacçaõ, e desempenho" (Lisboa, 7 de janeiro de 180o, in Carvalho, 1979, p. 153). Demonstrava-se à população a relevância do país, comprovando-se a grandeza da nação pela antiguidade e natureza das ruínas a descoberto. Naturalmente que, em 1798, Fracisco Xavier Fabri não terá gozado do particular apreço da população que, decerto, não terá visto com bons olhos a manutenção da cratera em local destinado à abertura da Rua de São Mamede (Fernandes, 2013, p. 51-62). A 16 de março de 1799, Jozé António Dias e Manuel Loureiro, proprietários do terreno onde se havia feito a descoberta, requerem a continuação dos trabalhos de edificação do seu imóvel (idem, p. 141). Teríamos de esperar por 1964 para que uma pequena sondagem realizada no $\mathrm{r} / \mathrm{c}$ do edifício, possibilitasse vislumbrar o que havia ficado, por tantos anos. subjacente ao imóvel de cinco pisos e águas furtadas sobreposto às vetustas pedras.

10. Cf. a este propósito Fabião, 2013, pp. 389-409.

11. Ou seja, tal como enumera “... Conservar o antigo Monumento no mesmo lugar, em que se achou, sou de parecer, que se compre o Terreno, e a parede dos Edificantes; e se torne a colocar outra vez no seu lugar parte das Pedras da Inscripção, que se tirarão para fora, antes de eu ser encarregado de vigiar sobre a indagação daquelas Antiguidades" (Carvalho, 1979).
A escavação arqueológica realizada naquele ano e depois continuada por Irisalva Moita até 1967 (Fernandes, em publicação) não correspondeu a um desejo da população, que desconhecia por completo o que permanecia no subsolo, antes a uma decisão de um restrito número de pessoas, letradas, académicas e de espírito empreendedor. Não fora tal circunstância, que aliou outras premissas ainda mais fundamentais - como a de convencer o poder político num investimento que a todos parecia estranho não teríamos tido no país um dos primeiros casos de arqueologia urbana e não teriamos hoje um sítio arqueológico musealizado e um museu a ele dedicado. É de sublinhar que o impacto que a escavação da década de 1960 teve nesta área da cidade foi considerável. A compra de vários edifícios e a demolição de cinco deles tendo por exclusivo objetivo aspetos culturais e científicos fez da operação imobiliária um caso absolutamente inédito. Um plano desta magnitude apenas poderia ter tido lugar num período de tempo tão rápido, no então contexto político. Apesar desta redescoberta auspiciosa, o destino das ruínas não seria ditoso. A "Revolução de Abril" trouxe novas premissas e as ruínas entre as ruas da Saudade e de São Mamede, foram apelidadas de "anti-revolucionárias". Num artigo de 16 de junho de 1974 no jornal A Capital, dizia-se (citando uma fonte, a propósito da expropriação dos edifícios a demolir) que “. .. uma descoberta de mero valor arqueológico (...) "é contrário aos principios democráticos do 25 de abril»".

As descobertas arqueológicas podem, afinal, ter um claro significado político e representar um atentado à própria comunidade, ou servir de arma de arremesso ao poder instituído. Não podemos deixar de mencionar que o baixo-assinado então apresentado à Junta Nacional da Câmara Municipal de Lisboa, contando com 86 assinaturas e manifestando-se contra o prosseguimento dos trabalhos arqueológicos, foi encabeçado por uma personagem revolucionária, Ary dos Santos, célebre poeta e compositor, embora não representando, em absoluto, a população. Na verdade, a grande maioria dos moradores ansiava pela expropriação dos imóveis e obtenção de novas casas com infraestruturas mais adequadas do que as que detinham.

Várias tentativas de impulsionar os trabalhos de descoberta do monumento cénico foram sendo pontualmente realizadas. A colocação de um tapume em redor da área, a manutenção de um guarda em per- 
manência, visitas guiadas a grupos específicos (especialmente académicos), ou o levantamento gráfico das estruturas arqueológicas, constituíram investimentos pontuais, mas sem traduzir uma verdadeira aposta na defesa do sítio arqueológico. A pessoa que se encontrava à frente de tal desígnio, Irisalva Moita, havia abraçado outras lutas. A população, por seu lado, nunca sentiu o local como seu, não percebendo o real interesse na manutenção à vista de tais pedras. O valor destas nunca lhes havia sido comunicado, explicitado, demonstrado ou valorizado (Figura 6 e 7 ).

Em 1989 a edilidade cria um Gabinete Técnico o qual promove novas intervenções arqueológicas. Este recomeço sublinhou a clivagem já existente entre a população local e a continuação do projeto de descoberta do monumento, devido à ausência de comunicação. A população não foi alertada do encerramento de uma das artérias (Rua da Saudade) ao trânsito viário, tal como não foram comunicados o reinício dos trabalhos de arqueologia e o objetivo subjacente a tais ações.

A criação de um museu em 2001 não alterou a situação, embora tenha pressuposto um substancial investimento económico por parte da edilidade. $\mathrm{Na}$ verdade, "Quando, em 2001, o Museu do Teatro Romano foi inaugurado, pouco se sabia do monumento cénico ao qual se dedicava um espaço museológico. (...) o espólio a expor era, por um lado, diminuto e, por outro, carecia de interpretação que não, a que ele próprio, poderia fornecer" (Fernandes, 20122013, p. 110).

A inexistência de um quadro técnico e de verbas destinadas ao museu e ao sítio arqueológico mais não fez que prolongar a situação de abandono do espaço, tendo a criação de um museu a ele dedicado sido a verdadeira prova, caso tal fosse necessário, que a criação de equipamentos não é o garante da defesa do património. Tal só viria a ocorrer a partir de 2016 quando a gestão do espaço transitou da edilidade para a empresa municipal EGEAC ${ }^{12}$. A partir desse momento foi possível planear verbas destinadas à programação cultural, promover novas intervenções arqueológicas, assegurar a publicação de vários trabalhos e, especialmente, criar um leque de atividades que promovessem o museu, o teatro e o reconhecimento do património latino na cultura atual.

12. Empresa de Gestão de Equipamentos e Animação Cultural.
Embora as campanhas arqueológicas e investigação sempre estivessem asseguradas, não existiam formas de divulgação acessível nem de captação de novos públicos ou dos residentes. Somente a partir de 2016, com a realização de exposições temporárias, publicações várias, atividades de sensibilização do património, tal panorama viria a ser alterado (cf. entre outros títulos: Fernandes, 2017-a, pp. 7-20; Fernandes, Grilo, 2020, pp. 69-87).

Atualmente o museu não se constitui como um espaço monográfico. A sua missão alicerça-se no estudo, salvaguarda e preservação do sítio arqueológico do teatro, mas esse é o ponto de partida da investigação diacrónica do lugar anterior à edificação do monumento e após o seu abandono. As estruturas arqueológicas preservadas no interior do museu, dos sécs. XVII/XVIII, são tão relevantes quanto aquelas de cronologia romana. São as várias estruturas que aproveitam o monumento romano - que nele se apoiam e lhe retiraram pedras e materiais que explicam a sua desagregação e destruição, mas, de igual modo, permitem perceber a reconstrução contínua da cidade até à atualidade.

Uma das primeiras exposições temporárias realizada pelo museu após a sua reabertura em 2015 foi Saudades da Rua da Saudade - o teatro romano e a sua envolvente nas memórias da cidade (2017). Tratou-se de um trabalho de recolha de depoimentos, escrito e em registo fílmico, da população local ainda residente e de outra, mais recente, que passou a habitar esta zona histórica. A ligação com a Junta de Freguesia foi imediata, sendo a instituição que melhor conhece a população. O local escolhido foi precisamente a Galeria de Exposições Temporárias da Junta de Freguesia de Santa Maria Maior.

A "Hora de Baco", outra das iniciativas realizadas no museu, tenta recriar o ambiente dos antigos teatros, como ocorria originalmente no teatro de Pompeu, em Roma. Uma vez por mês o museu abre as portas gratuitamente, com horário de visitas alargado. Após cinco anos, esta iniciativa já se tornou num momento de encontro da população, amigos, residentes e de público sénior e também jovem.

O museu pretende ser um espaço de partilha e de encontro, um local seguro onde as ruínas arqueológicas sejam vistas, vividas e sentidas mas onde todas as iniciativas têm, subjacente, uma fundamentação científica, pedra basilar da sua estrutura programática.

A missão do museu tem sido norteada pela inclusão, onde a comunidade local assume especial rele- 
vância. Tem sido dada especial atenção a temas da cultura clássica, salvaguarda do património e à arqueologia, através de palestras, exposições e festividades que procuram comemorar datas relevantes do calendário romano, como ocorre com a celebração das festas da Parentalia, Lupercalia ou Saturnalia. O Festival de Teatro Clássico, realizado no mês de julho é já uma marca identitária do museu, levando à cena no sítio arqueológico, algumas obras clássicas marcantes, como A Paz de Aristófanes, O Misantropo de Menandro, Édipo Rei de Sófocles ou a Medeia de Eurípides (Figuras 8 e 9). Esta é precisamente, a maior vocação do sítio arqueológico: devolver à população um dos palcos mais antigos do território nacional.

Cumpre-se assim o que consideramos a inteira vocação museológica deste sítio arqueológico: promover a sua vivência pela população de hoje, cumprindo a vocação para a qual foi edificado: o de ser teatro!

\section{CONSIDERAÇÕES FINAIS}

As ruínas, entendidas como sítios arqueológicos contêm histórias. Em espaços urbanos, especialmente, são muitas as histórias que encerram, paralelas ao número de construções e derrubes, reconstruções e remodelações que o espaço habitado é alvo. As histórias encerradas num sítio arqueológico não comunicam intencionalmente uma ou outra informação. Não foram construídos com esse objetivo e as informações que encerram apenas cumprem o seu objetivo se forem descobertas, interpretadas e transmitidas.

As ruínas são verdadeiramente democráticas pois pertencem a todos e surgem em todo o lado. No entanto, essa democratização só se cumpre se houver concenso na decisão da sua manutenção à vista e se a informação que encerram conseguir alcançar quem as vê, transformando-se, como refere Huges de Varines, em "património vivo".

O património é de todos e para todos e todos temos o direito, mas também o dever, de participarmos na sua construção (Schofield, 2015, p.418). Esta participação exige-se enquanto usufruidores do património, mas, de igual modo, como elementos valorizadores do mesmo, entendido o objeto e o visitante como elos de uma mesma ligação onde apenas os dois, em simbiose, fazem viver o outro.

Se esta ligação biunívoca é expectável num museu, mais pertinente se torna nos sítios arqueológicos.
Entendidos os visitantes como "valorizadores do património" a ligação próxima que se estabelece com um sítio arqueológico - por ser algo compreensível e materialmente reconhecível - tem de ser valorizado. A musealização de um sítio arqueológico é a sua vocação natural se o sentido de pertença for partilhado.

\section{BIBLIOGRAFIA}

A Capital (1974), Jornal diário, 19 junho, p. 14.

ALARCÃO, Pedro (2018) - Construir na Ruína, entre a Reconstrução e a Reabilitação. Ed. Afrontamento

BAHN, Paul G. (1996) - Archaeology: A Very Short Introduction. Oxford University Press

CARVALHO, Ayres de (1979) - Os três arquitectos da Ajuda do "Rocaille" ao Neoclássico. Manuel Caetano de Sousa (1742-1802) José da Costa e Silva (1747-1819) Francisco Xavier Fabri (1761-1817). Lisboa, Academia Nacional de Belas-Artes, pp. 135-153.

CARMAN, J. (1999) - Settling in sites: constraining concepts. In BRUCK, J, \& GOODMAN, M. Ed. Making places in the prehistoric world. London, University College London, pp. 20-30.

FABIÃO, Carlos (2013) - Escavando entre papéis: sobre a descoberta, primeiros desaterros e destino das ruínas do teatro romano de Lisboa. Vir bonus peritissimus aeque. Estudos de homenagem a Arnaldo do Espírito Santo. Centro de Estudos Clássicos. Faculdade de Letras de Lisboa. Lisboa, pp. 389-409.

FEDER, K. L. (1997) - Site Survey. In Hester. Methods in Archeology, (T. H., Feder, K. L. \& Shafer, H. J., Field). Connecticut: Mayfield Publishing.

FERNANDES, Lídia (2012-2013) - O Museu do Teatro Romano (Lisboa): um teatro, um museu e um projecto de investigação. Revista Arqueologia \& História, vol. 64-65, pp. 109-123.

FERNANDES, Lídia (2013) - Museu do Teatro Romano (2001-2013): Balanço de uma década de intervenção e novos projectos para o espaço museológico. Revista Almadan. Centro de Arqueologia de Almada. IIª série, p. 51-62.

FERNANDES, Lídia (2017) - Museu de Lisboa - Teatro Romano: um museu e um monumento romano na cidade. I Encontro de Arqueologia Urbana: uma cidade em escavação (Teatro Aberto, 26-28 novembro 2015). Lisboa, p. 193-211.

FERNANDES, Lídia (2017-a) - Teatro Romano de Lisboa: as ruínas e o seu museu ou como a arqueologia promove o diálogo educacional. Revista Temporis [ação]: 17, nº 2, pp. 7-20.

FERNANDES, Lídia (em publicação) - Irisalva Moita e o processo de escavação do teatro romano de Lisboa. Revista Scaena, $\mathrm{n}^{\circ} \mathbf{2}$. 
FERNANDES, Lídia; GRILO, Carolina (2020) - Teatro Romano de Lisboa: para além do museu e do sítio arqueológico. $3^{\underline{a}}$ Edição Workshop Internacional ARQUEOLOGIA 3.o. 'Resgatar Memórias' (14 - 15 Março 2019 (Fundação da Casa de Bragança - Museu-Biblioteca da Casa de Bragança Universidade de Évora - CHAIA) pp. 69-87.

PÉREZ-PRAT DURBÁN, Luis (2018) - Las ruinas en la lista del Patrimonio Mundial de la UNESCO. Las Ruinas, Concepto, Tratamiento y Conservación. Maria del Valle G. de Terreros Guardiola, Luis Pérez-Prat Durbán (Eds.). Universidad de Huelva, pp. 89-101.

Saudades da Rua da Saudade - o teatro romano e a sua envolvente nas memórias da cidade (2017). VV autores (Org. Museu de Lisboa - Teatro Romano / EGEAC).
SCHOFIELD, John (2015) - Thinkers and Feelers: A Psychological Perspective on Heritage and Society E. Waterton e S. Watson, eds., The Palgrave Handobook of Contemporary Heritage Research, Basingstoke and New York, Palgrave Macmillan, pp. 417-425.

VARINES, H. de (200o) - O Ecomuseu. Ciências e Letras, 27, Porto Alegre, pp. 61-9o.

https://commons.wikimedia.org/w/index.php?curid= 17309641. De Anual - Trabajo propio, CC BY-SA 3.o (Acedido a 8 julho, 2020).

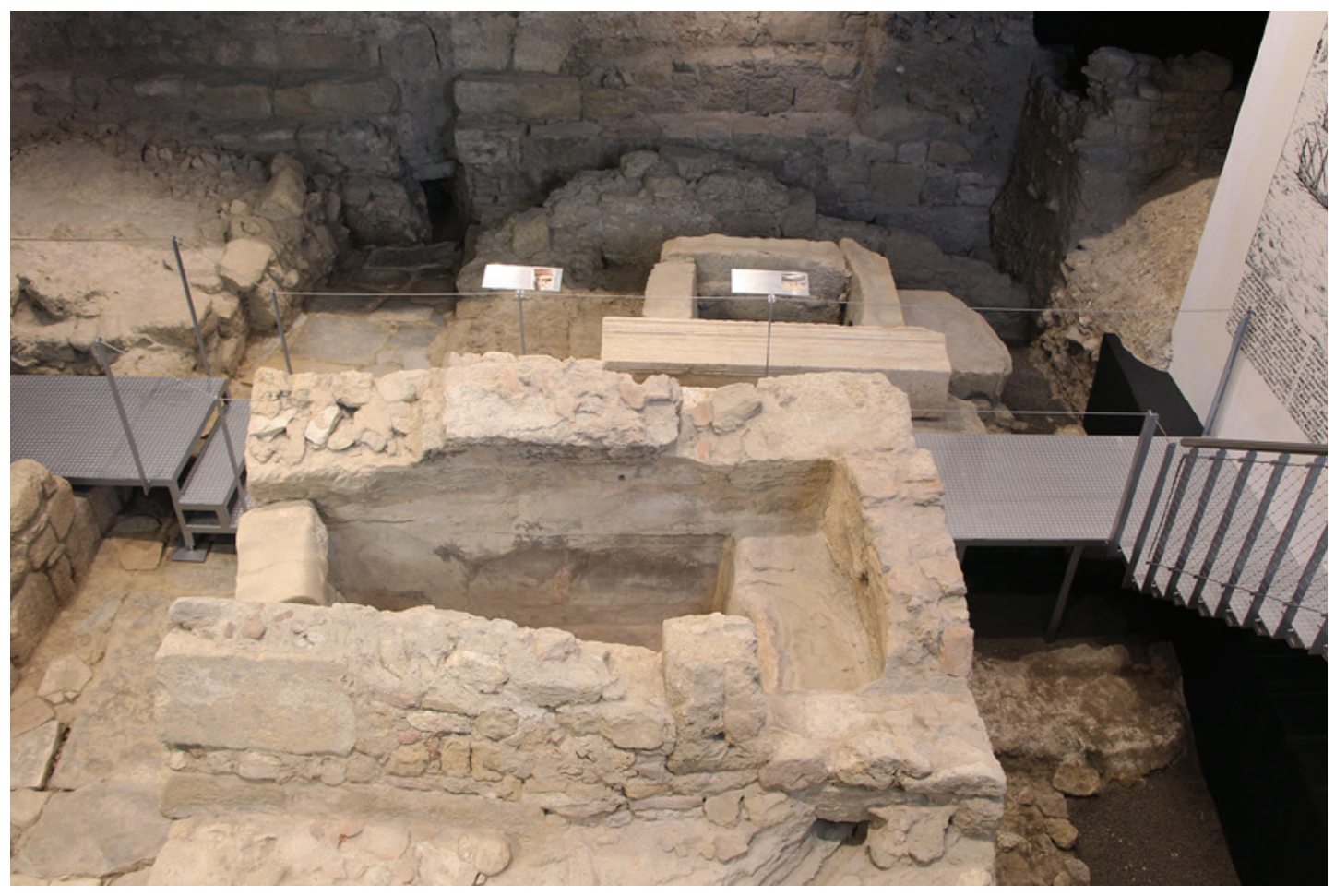

Figura 1 - Estruturas arqueológicas musealizadas no Hotel Eurostars Museum, em Lisboa. (Fotografia de Lídia Fernandes). 


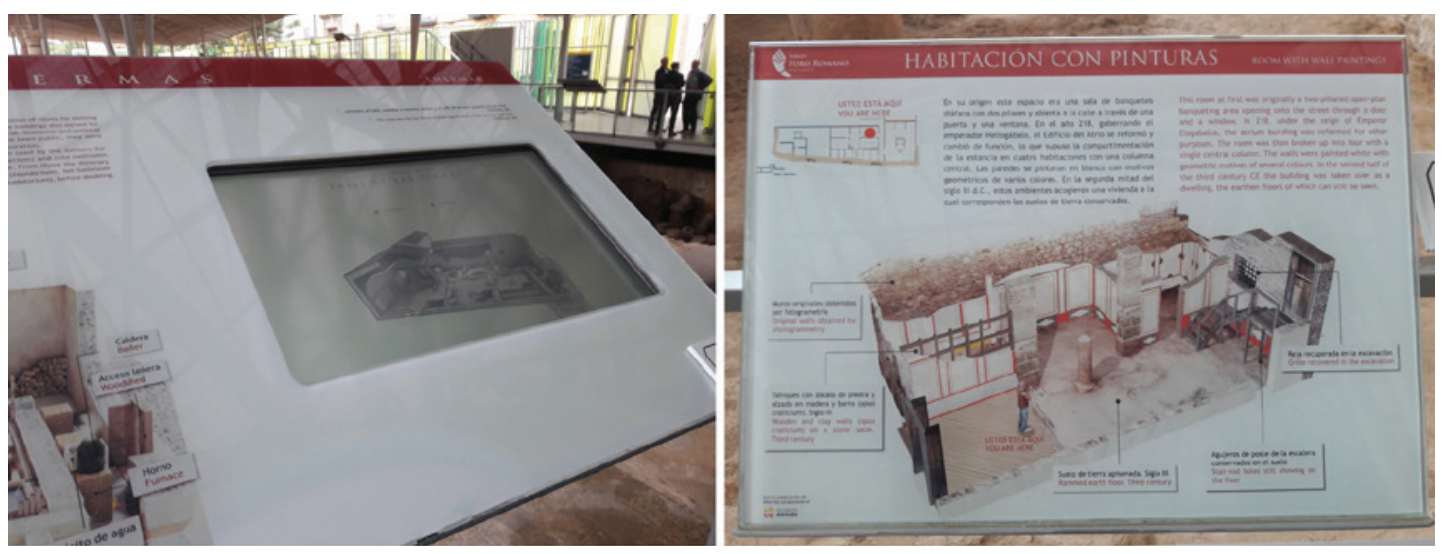

Figura 2 - Parque Arqueológico Cerro del Molinete (Cartagena, Espanha). Diversos suportes, diferentes meios de informação: digital, reconstituições 2D e 3D, auscultadores, textos informativos, legendas. (Fotografia de Lídia Fernandes).

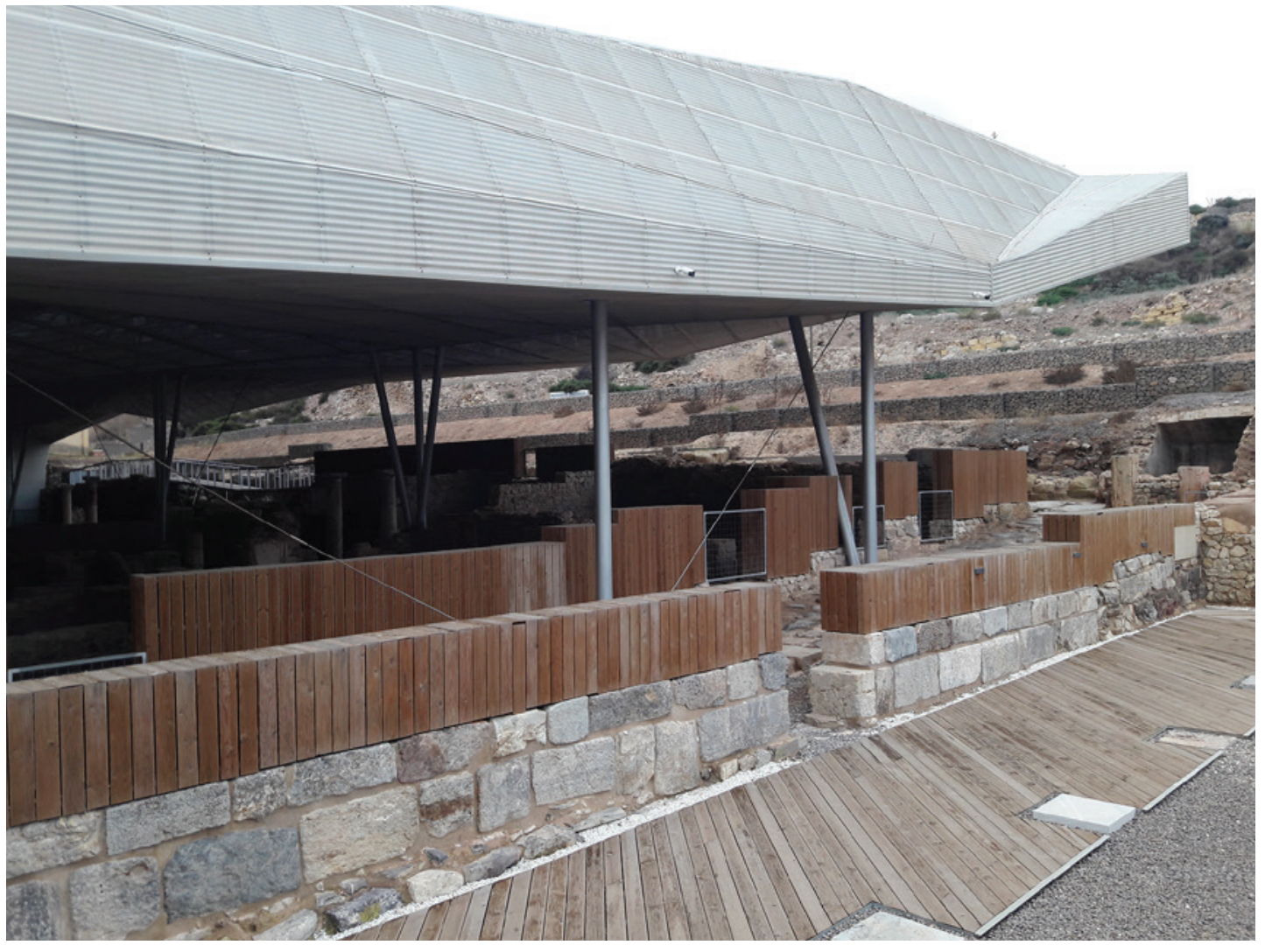

Figura 3 - Parque Arqueológico Cerro del Molinete (Cartagena, Espanha). Cobertura, pavimentos e separação da área coberta das estruturas ao ar livre (Fotografia de Lídia Fernandes). 


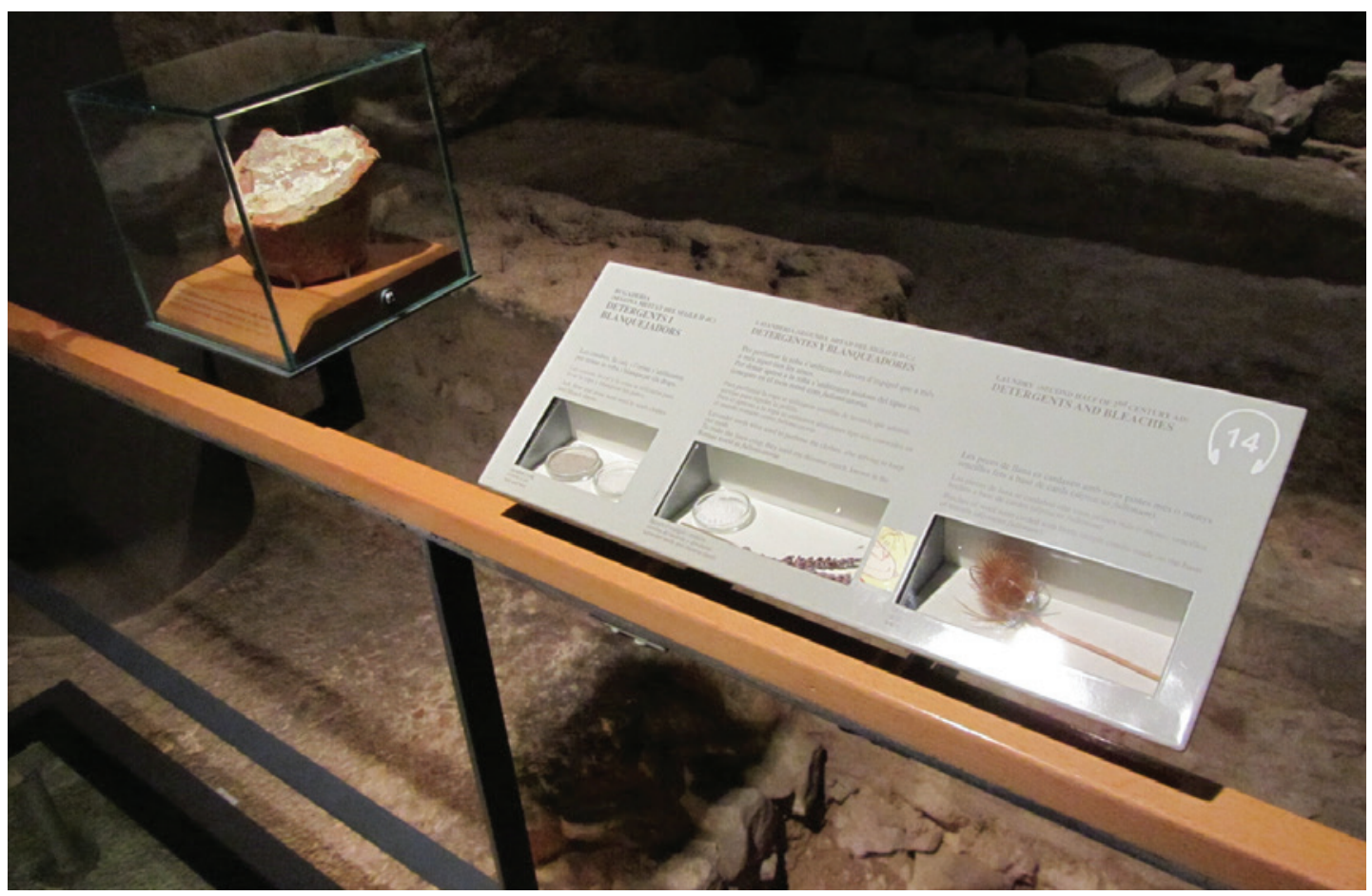

Figura 4 - Subterrâneos do Museu d'Historia de Barcelona. Exposto está o fundo de um recipiente cerâmico com vestígios de pigmentos, ao lado estão plantas e produtos usados no branqueamento e lavagem de tecidos. Estes elementos encontram-se diante das estruturas arqueológicas de uma lavandaria romana do séc. II d.C. (Fotografia de Lídia Fernandes).

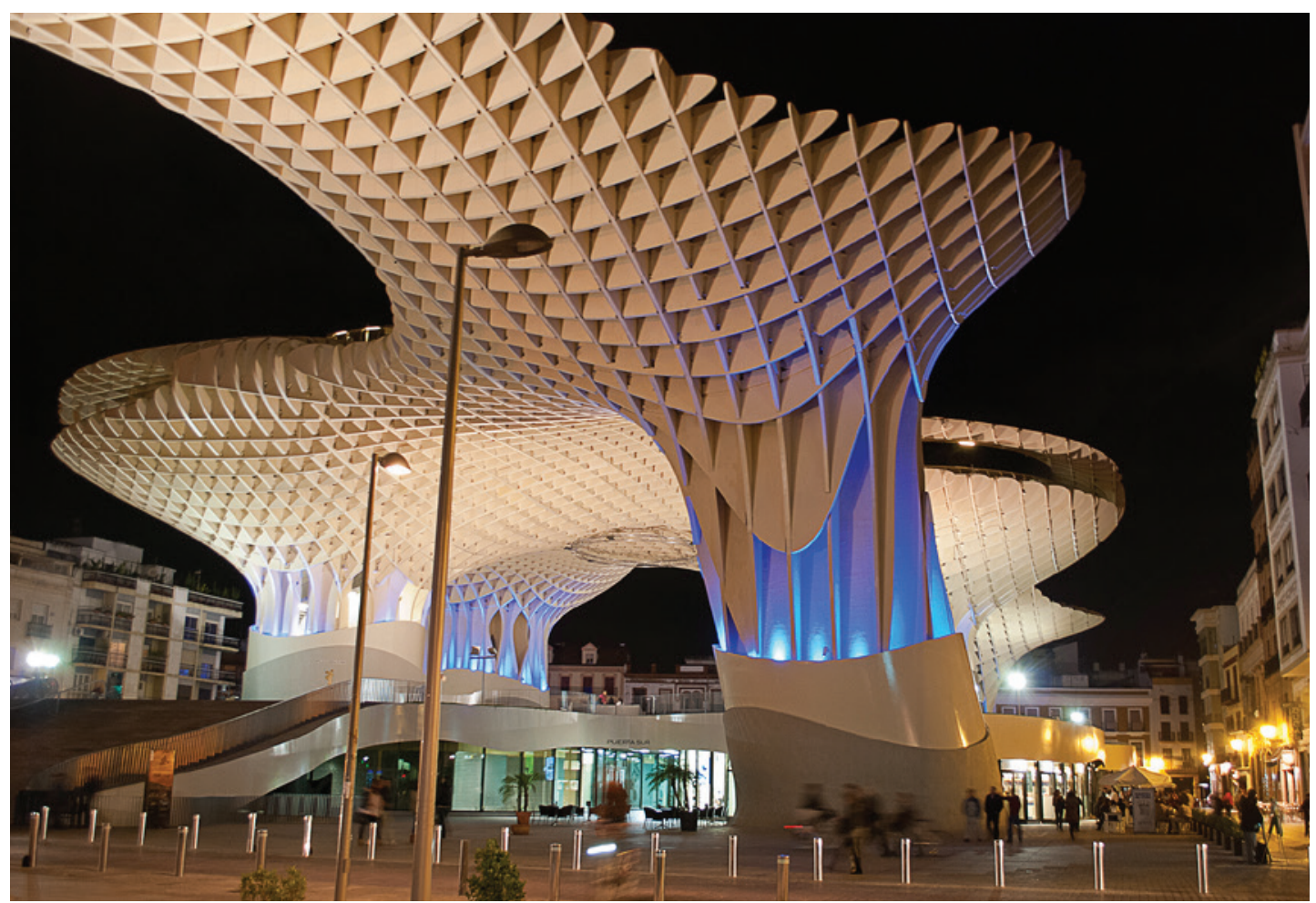

Figura 5 - Metropol Parasol (Plaza de la Encarnación, Sevilha). https://commons.wikimedia.org/w/index. php?curid=17309641. De Anual - Trabajo propio, CC BY-SA 3.0 (Acedido a 8 julho, 2020). 


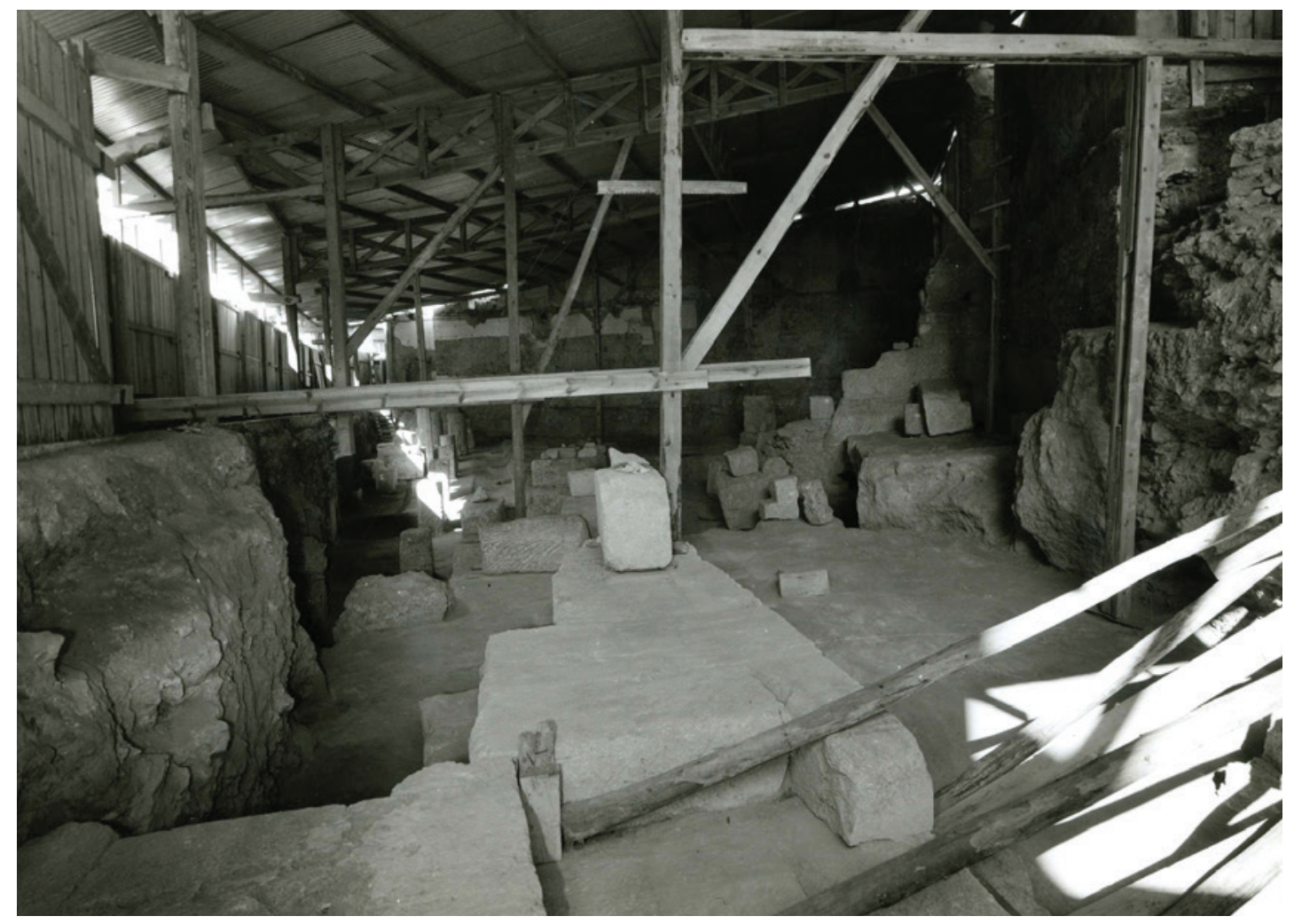

Figura 6 - Ruínas do teatro romano no final das campanhas de escavação da década de 196o. (Arquivo Municipal de Lisboa).

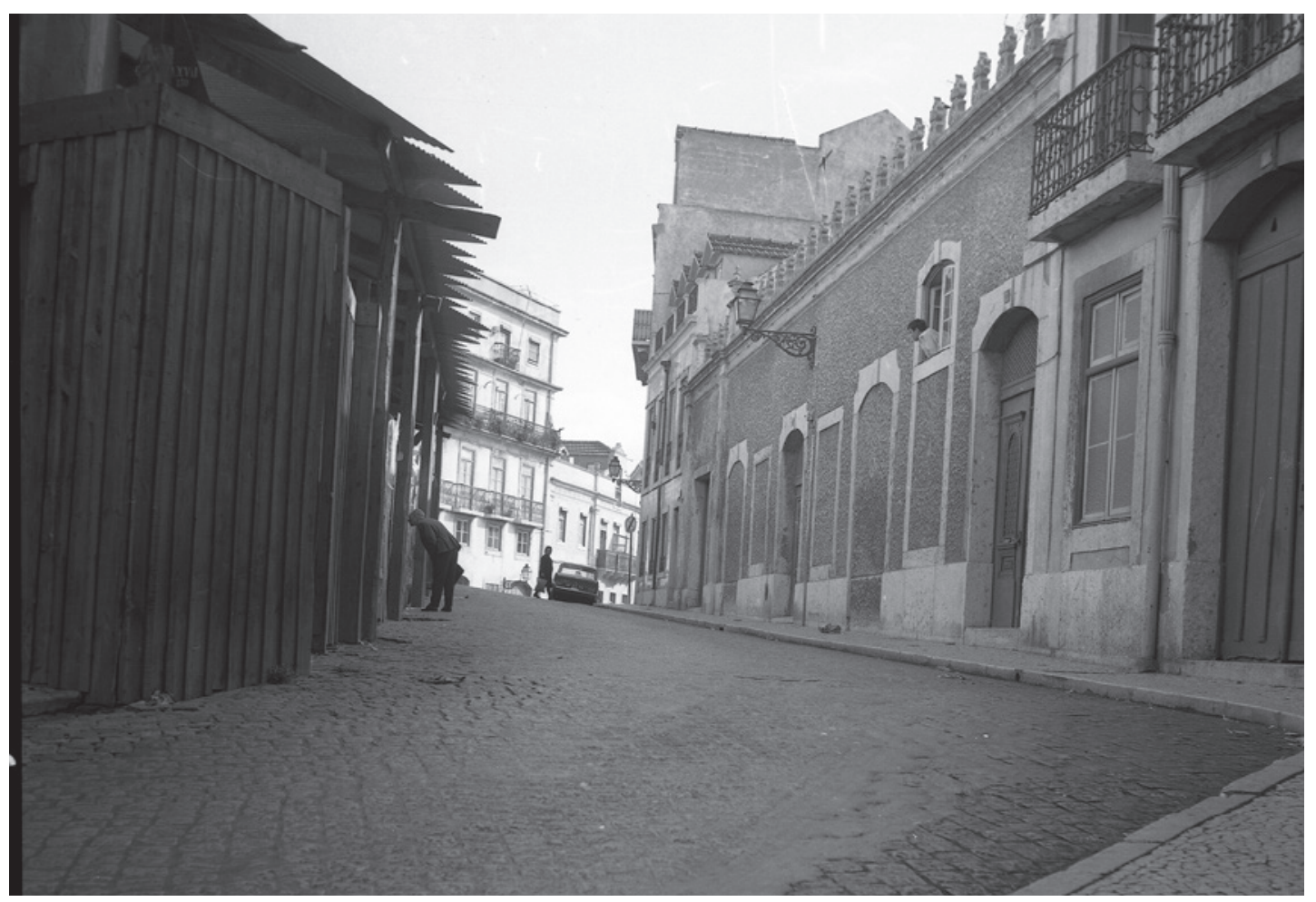

Figura 7 - Tapume de madeira colocado na década de 1960 para proteção das ruínas na Rua de São Mamede. (Arquivo Municipal de Lisboa). 


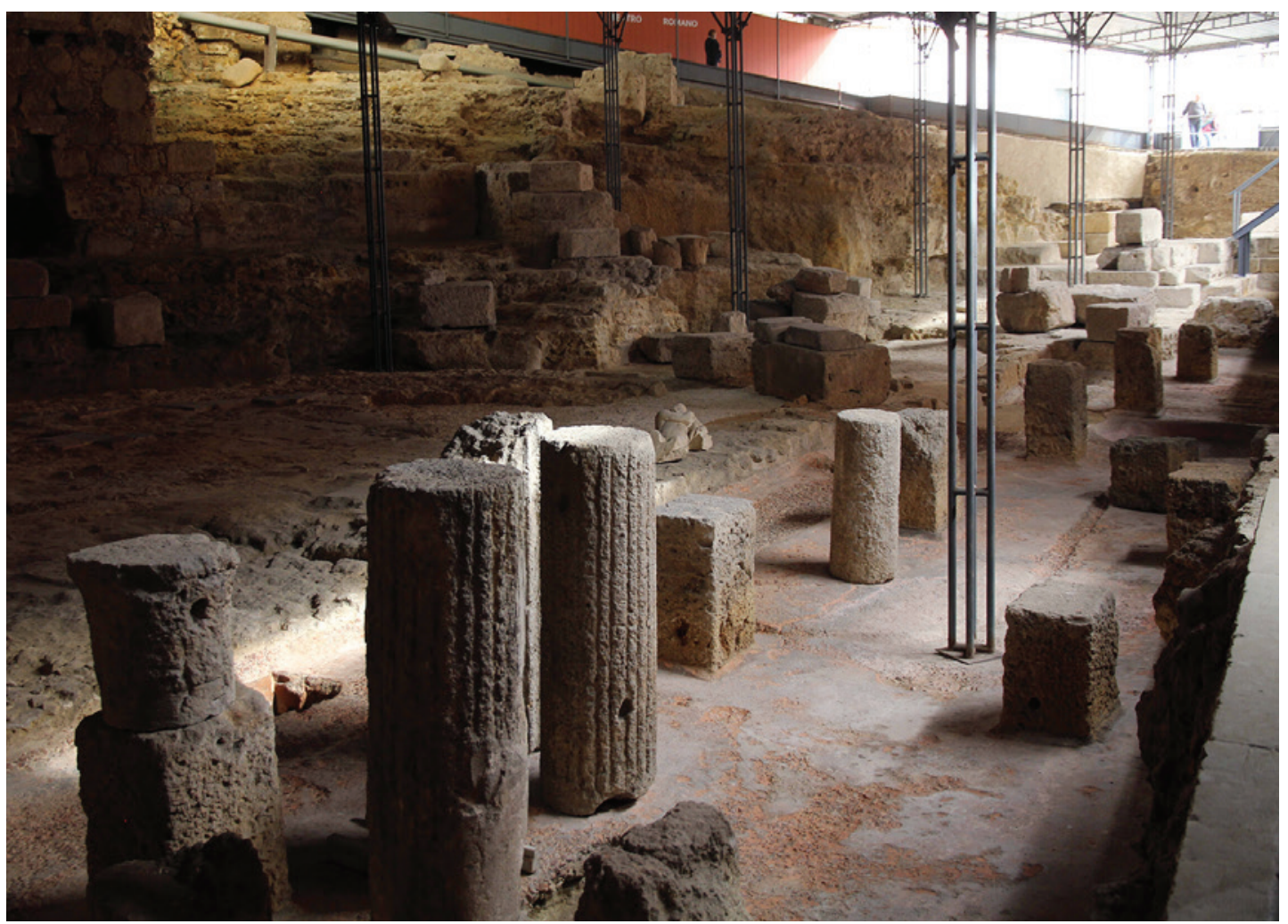

Figura 8 - O sítio arqueológico do teatro romano. (Fotografia de José Avelar).

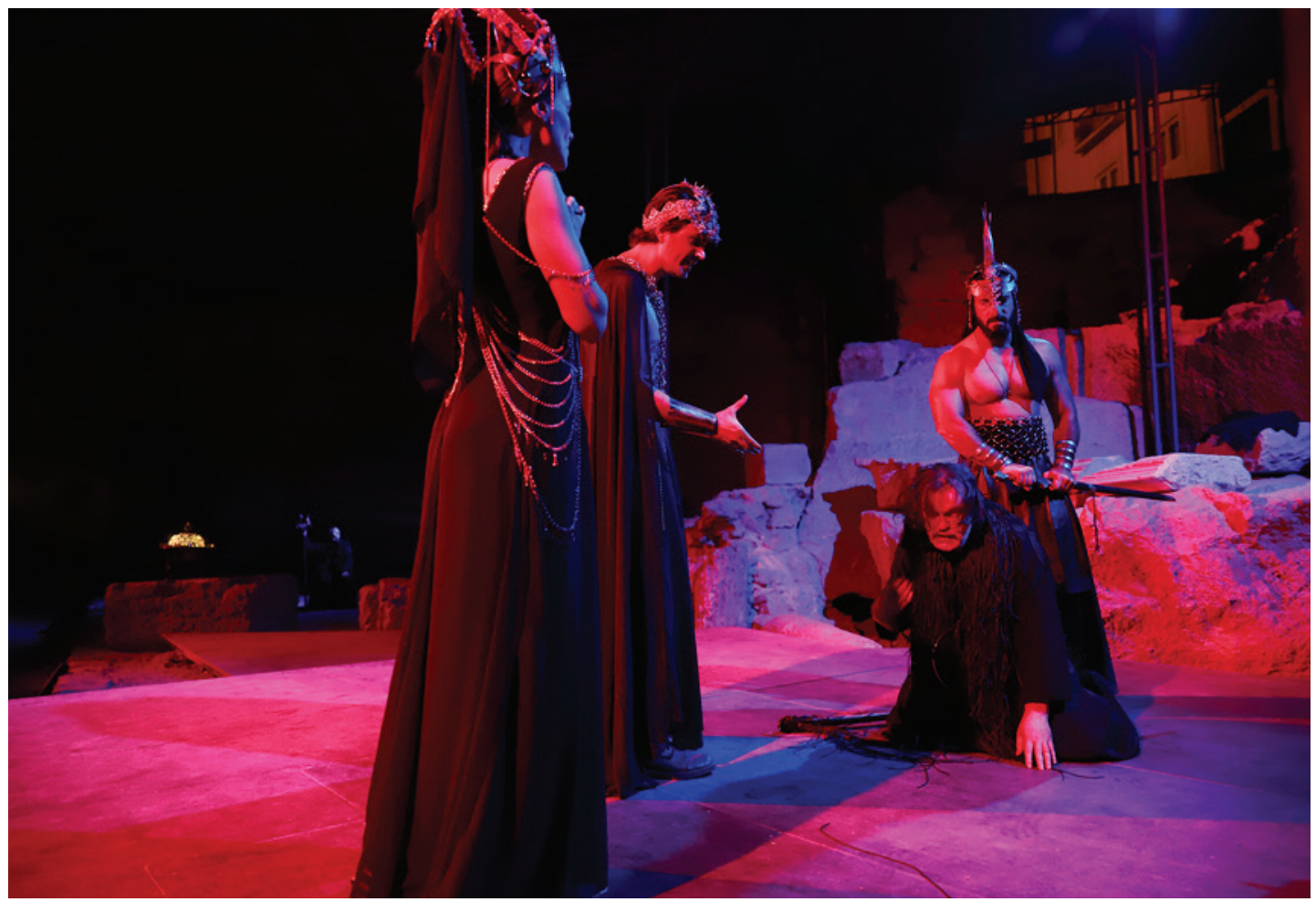

Figura 9 - A peça Rei Édipo encenada pelo Teatro Livre em 2019 (Fotografia de José Avelar). 


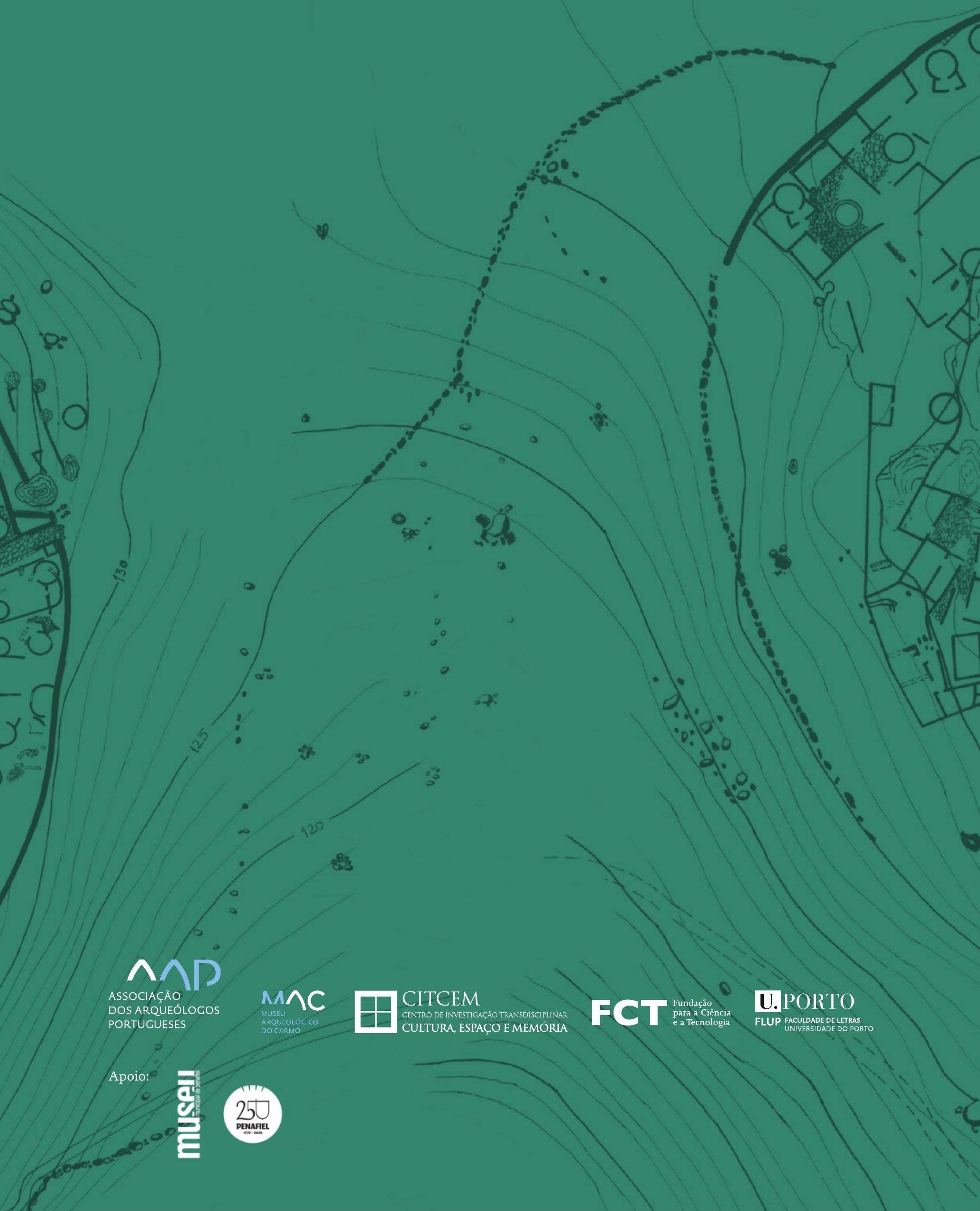

